\title{
A Christmas Issue: Christian Holiday Celebration in the Public Elementary Schools Is an Establishment of Religion
}

\author{
John M. Hartenstein $\uparrow$
}

The Supreme Court has never addressed the constitutionality of public elementary school Christmas holiday observances. This Comment argues that such celebrations offend the Establishment Clause of the First Amendment. The author begins by discussing the role of religion in the American immigrant's struggle for identity in a new homeland and the ways in which religious observances provide identity to all people, especially religious and ethnic minorities. With this background, he then turns to the schools, arguing that Christmas rituals inevitably express sectarian Christian religious content, and thus are a kind of proselytization that violates the Establishment Clause of the First Amendment when sponsored by public schools. The author applies each of the existing Supreme Court theories of Establishment Clause violations-the Lemon test's purpose, effect, and entanglement branches; Justice O'Connor's "endorsement" test; and Justice Kennedy's "coercion" test-to the problem of public elementary school Christmas holiday observances. Taking into account the impressionability of elementary school students, compulsory school attendance, and the perspectives of non-Christians, the author concludes that public school Christian holiday observances should be found unconstitutional. The First Amendment must protect not only the religious beliefs of Christians but also the religious identities of all Americans. To faithfully uphold the Establishment Clause of the First Amendment, the Court must take into account the perspectives of non-Christian members of society. Only by eliminating religious observances from elementary schools can government protect the religious interests of all Americans.

$\dagger$ Associate, Orrick, Herrington \& Sutcliffe, San Francisco, California. B.A. 1980, University of California, Berkeley; M.P.P. 1985, John F. Kennedy School of Government, Harvard University; J.D. 1991, Boalt Hall School of Law, University of California, Berkeley. The author, a nonreligious Jew, and his wife, a nonreligious Muslim, live in Berkeley with their daughter Meena, whose kindergarten's celebration of the Mexican Catholic holiday El Dia de los Muertos ("The Day of the Dead") was the seminal event leading to this Comment. The author extends his appreciation to Dr. Michael R. Flick, Editor-in-Chief of the California Law Review (1991-92) for his significant improvement to this Comment. 
Christmas, I suppose, is still a religious celebration, not merely a day put on the calendar for the benefit of merchants.

$$
\text { -Justice William O. Douglas }{ }^{1}
$$

It is difficult to imagine walking into an elementary school after Thanksgiving and not seeing evidence of the impending Christinas holiday. Because the Supreme Court has prohibited rehigious prayer in public schools, ${ }^{2}$ most schools try to avoid conveying any explicit Christian 1nessage in their holiday observances. ${ }^{3}$ Diversity of ethnicity and religious practice in many urban areas has also led solne schools to include otller hohday observances in their "winter loliday"4 celebrations. 5 But Christmas is so widely accepted and entrenched in American culture that its religious origins and content are usually overlooked, and few would seriously consider altogether proscribing Christınas observances in public elementary schools.

The Supreine Court's view of the constitutional significance of Christmas mirrors tliat of 1nost Americans. Although it has never addressed the constitutionality of public elementary school holiday observances, ${ }^{6}$ the Court has found that observance of Christinas and Hanukkalı by public entities does not necessarily violate the First Amendment's coinmand, made applicable to the states by the Fourteenth Amendinent, that government "shall inake no law respecting an establishment of religion, or prohibiting the free exercise thereof."7 My purpose is to challenge the Cliristian perspective of the general American public and legal commumity by introducing an understanding of what religion and religious freedom can mean to religious minorities and by demonstratimg that what the inajority of Cliristian Ainericans consider secular is not religiously neutral to non-Cliristians. I apply existing Supreine Court theories of Establishment Clause violations-the Lemon

1. Engel v. Vitale, 370 U.S. 421,442 n.8 (1962) (Douglas, J., concurring).

2. Engel v. Vitale, 370 U.S. 421 (1962).

3. See, eg., Don Lattin, New Drive for Studying Religion in the Schools, S.F. Chron., Dec. 22, 1989, at A1.

4. County of Allegheny v. ACLU, 492 U.S. 573, 616 (1989) (plurality opinion).

5. See Lattin, supra note 3. Examples of other celebrations include Las Posadas, a Mexican observance in honor of the story of Mary and Joseph's search for lodging, and Kwanzaa, an "African" harvest festival invented in the 1960 s to offer American blacks an alternative to Christunas and Hanukkah. Id. For an account of Kwanzaa, see CEDRle MCClester, KwanzaA: Everything You Always WANTED to KNOW BUT DidN'T KNOW Where to ASK (1990).

6. One circuit court, however, has found them constitutional. Florey v. Sioux Falls Sch. Dist. 49-5, 619 F.2d 1311 (8th Cir.), cert. denied, 449 U.S. 987 (1980). Florey is discussed briefiy infra note 171 and more comprehensively in Steve L. Pevar, Public Schools Must Stop Having Christmas Assemblies, 24 ST. LoUIS U. L.J. 327 (1980) (arguing that because Christnas is a religious holiday, school officials may not bring its celebration into the classrooin).

7. U.S. CONST. amend. I; Everson v. Board of Educ., 330 U.S. 1 (1947); see also County of Allegheny v. ACLU, 492 U.S. 573 (1989) (public display of Hannukah menorah upheld); Lynch v. Donnelly, 465 U.S. 668 (1984) (crèche display by city upheld). 
test, ${ }^{8}$ Justice O'Connor's "endorsement" test," and Justice Kennedy's "coercion" test ${ }^{10}$ - to hohday observances in public schools and argue that, taking into account the impressionability of elementary school students and the perspective of non-Christians, public school holday observances should be found unconstitutional. ${ }^{11}$

Part I of this Comment discusses the history of the American immigrant's search for identity im a new homeland and the central role of religion in that struggle. Part II examines the way in which rehigious observances provide identity to all people, especially rehgious and ethnic minorities. While Christians define themselves primarily in terms of belief or faith, religions such as Judaism, Islam, Zen Buddhisin, and other non-Clrristian rehgions, especially as manifested in the Umited States, tend to define their nembers by practice and ritual rather than by belief in god. Part III examines constitutional law regarding rehigious indoctrimation in the public schools and the observance of rehigious hohdays by public entities. The Supreme Court has not yet addressed the issue of whether holiday celebrations in public elennentary schools are a form of religious indoctrimation or a form of permissible public celebration. I argue that Christmas rituals inevitably express religious content, and thus violate the Establishnient Clause of the First Amendment when sponsored by public schools. The First Amendinent should protect not only the religious beliefs of Christians but also the religious identity of religious minorities. The Supreine Court tends to treat Christian worship as the model by which all rehigious activity should be judged under the First Amendment, resnltimg in a demal of First Amendment protection to religious minorities. To faithfully uphold the Establishnient Clause of the First Amendment, the Court must take into account the perspectives of non-Christian inembers of society. Only by eliminating religious observances froin elementary schools can government protect the religious interests of all Americans.

8. Lemon v. Kurtzman, 403 U.S. 602 (1971) (setting out three-part test examining purpose, effect, and "entanglement").

9. Lynch, 465 U.S. at $688-94$ (O'Connor, J., concurring) (clarifying Lemon); Wallace v. Jaffree, 472 U.S. 38, 76 (1984) (O'Connor, J., concurring in the judgment) (introduction of the "objeetive observer"); Allegheny, 492 U.S. at 592-94 (majority applying "endorsement" test).

10. Allegheny, 492 U.S. at 655 (Kennedy, J., concurring in part and dissenting in part) (setting out "coercion" test).

11. I focus only on the celebration of Christmas in the public elementary schools, but the analysis is equally applicable to other religious holidays-such as Easter, feast days of the Christian saints Patrick and Valentine, and Halloween - that are widely observed in schools. Readers should also bear in mind that holiday traditions of other cultures, introduced in the schools to balance the celebration of Christian or "American" holidays, likely have strong religious origins and overtones even though they may appear secular to most Americans. 
From THE OUTSIDE LOOKING IN: THE IMMIGRANT AND RELIGIOUS TOLERANCE

\section{A. Becoming an American: The Processes of Immigration and Assimilation}

American immigration has always posed the same questions for American culture: How must the immigrant change to fit into American society? How must American society adapt to accommodate the new imimigrant? This Section discusses the assimilation process that the immigrant undergoes in becoming American and concludes that religion is often a central aspect of the immigrant's identity-an aspect that the immigrant is not expected to forsake upon integration into American society.

Assimilation can be generally defined as the process by which people of two cultures merge and cultural differences disappear. ${ }^{12}$ Professor Milton Gordon identified several subprocesses of assimilation, the most significant of which were "cultural assimilation," or changing one's cultural patterns, including religious behefs and observances; "structural assimilation," or entering social groups and institutions; "identificational assimilation," or ethmic self-identification with the inajority culture; and "inarital assimilation," or large-scale intermarriage. ${ }^{13}$ By examining the degree to which American immigrants have achieved these subprocesses, Gordon evaluated how successfully different ethnic iminority groups have been assimilated. ${ }^{14} \mathrm{He}$ concluded that not only is "cultural assimilation" probably achieved first but that it is also the only subprocess some immigrant groups ever complete. ${ }^{15}$ The assimilation process does not necessarily, however, lead to the immigrant's absorption into the host culture. Gordon evaluated three different inodels that describe the varying types of interaction between the immigrant group and the host culture: the "melting pot" theory, "cultural pluralism," and "Anglo-conformity."16

The melting-pot theory "envisaged a biological merger of the AngloSaxon peoples with other immigrant groups and a blending of their respective cultures into a new indigenous American type."17 While this model might accurately describe the intermarriage that occurred among early European inmigrants of English, Irish, German, Huguenot, Dutch,

12. Milton M. Gordon, Assimilation IN AMERICAN Life 61-68 (1964) (reviewing various definitions of assimilation offered by scholars).

13. Id. at 70-71 (tbl. 5). Gordon also noted that "structural assimilation" is particularly significant because once it is achieved, the other subprocesses follow. Id. at 81 .

14. Id. at $75-80$.

15. Id. at 77.

16. Id. at 85. Gordon identified these models normatively as " 'philosophies' or goal-systems of assimilation," yet he examined each descriptively in terms of historical application. See generally id. at 84-159 (detailed analysis of each model).

17. Id. at 85 . 
and Swedish stock, ${ }^{18}$ it is not generally apphicable to the experience of most other immigrants. ${ }^{19}$ The melting-pot idea also fails to describe how the resulting "race" came to identify itself in cultural terms.

The concept of cultural pluralism does not suffer from such limitations. This theory postulates that immigrants retain significant portions of their hoine culture while adopting American citizenship and integrating into a single American pohitical and economic system. ${ }^{20}$ While this inodel might fairly describe what was observed in many immigrant groups throughout the colomial period and nineteenth century, ${ }^{21}$ it actually blurs two separate observations: for long periods of American history new immigrants continued to flow into the country, keeping the immigrant culture alive with new blood; meanwhile, earher immigrant families tended to discard their home-country culture and became absorbed into the existing American cuiture. ${ }^{22}$

According to Gordon, the inost comprehensive explanatory paradigm of assimilation treating American history from the period of coloniahism to the present is the Anglo-conformity model. This "demanded the complete renunciation of the immigrant's ancestral culture in favor of the behavior and values of the Anglo-Saxon core group."23 The Anglo-conformity model assumes the desirability of maintaining Enghish institutions, language, cultural patterns, and even racial types as standard. ${ }^{24}$ It involves adopting Anglo-Saxon ideal "types" as our mythical heroes (such as Washington and Lincohi) and as our icons of popular culture. ${ }^{25}$ The Anglo-conformity model can explain, for example, how sharing the dominant Anglos' language allowed the Irish to successfully assimilate despite being a foreign, Catholic group. ${ }^{26}$

Professor Gordon concluded that immigrants neither shaped a new hybrid American society nor achieved cultural pluralisin. Instead, the prior existence of Anglo institutions, the pervasiveness of the English language, and the dominance of the Anglo-Saxon population forced latecomers to fit into "existing white Protestant society."27 When immigrants did not achieve this conformity willingly or rapidly enough, they were helped along by pohtical and social "Americanization" movements based on suspicion and contempt of the non-Anglo foreigner. ${ }^{28}$ In sum,

18. Id. at 87.

19. Id.

20. Id. at 85 .

21. Will Herberg, Protestant-Catholic-Jew: An Essay in American Religious Sociology 33 (1956).

22. Id.

23. GORDON, supra note 12 , at 85 .

24. Id. at 88.

25. HERBERG, supra note 21 , at 33-35.

26. Id. at $157-63$.

27. GORDON, supra note 12, at 127.

28. Id. at $98-103$. 
America has not been a melting pot. Rather, it has been a " 'transmuting pot' in which all ingredients have been transformed and assimilated to an idealized 'Anglo-Saxon' model."29

Assuming that assimilation in the Anglo mold is the path down which immigrants are led into American culture, it is important to know how extensively and in what areas immigrants must assimilate im order to succeed. ${ }^{30}$ Professor Will Herberg articulated a useful starting point, suggesting nationality, language, and culture as some of the things immigrants must surrender in order to become American. ${ }^{31}$ In return, they must accept the "religion of democracy": the unifying "American Way of Life" and its faith in free enterprise, the Constitution, egalitarianismand even sanitation. ${ }^{32}$

Recent demands that immigrants adopt the Enghish language are an exaniple of the Herberg hypothesis. Although there have been trends toward bilingual education and ballots, many states have seen pohitical efforts to assert the primacy of English with legal force. ${ }^{33}$ Generally, immigrants who do not adopt the language become and remain ghettoized or at least assimilate much more slowly. ${ }^{34}$ Beyond pohtical and social standards, the degree to which the state may dictate personal aspects of the immigrant's life is limited. While states may, for exaniple, prohibit marriage arrangenents in violation of the American norms of monoganiy, heterosexuality, and adulthood, ${ }^{35}$ the state may not compel a

29. HERBERG, supra note 21 , at 33-34.

30. Failure to achieve the right amount of assimilation can be costly to any group. See GoRDON, supra note 12, at 108-09 (examining Black, Indian, and Hisparic minorities). Considering that the nornative model of assimilation has been Anglo-confornity, it is not surprising that those least able to achieve assimilation have been those most racially, and thus immutably, unlike the prototype. Id. at 129 .

31. HERBERG, supra note 21 , at 35 .

32. Will Herberg, America's Civil Religion: What It Is and Whence It Comes, in AMERICAN CIVIL Religion 76, 79 (Russell E. Richey \& Donald G. Jones eds., 1974). Regarding sanitation, Herberg cited a placard posted in many restaurants across the country that read: "Sanitation is a way of life. As a way of life, it must be nourished from withm and grow as a spiritual ideal in human relatious." Id.

33. See Keith White, Sponsor Renews Push to Make English the Official Language, Gannett News Service, Sept. 17, 1991 (18 states have already declared English their official language), available in LEXIS, Nexis Library, GNS File.

34. See GoRdon, supra note 12, at 108-09. Of course, at appropriate times and places Americans also embrace their minorities' colorful folk traditions, music, and exotic cuisines. These things enrich public pageants, give expression to the full diversity this country represents, and remind each American of his or her own forsaken heritage. See, e.g., id. at 138 (describing the "Labor Museum" created by Jane Addams at Hull House, where immigrant women demonstrated their native spinning and weaving techniques in order to create and inaintain awareness of their cultures among the different members and generations).

35. See, e.g., Reynolds v. United States, 98 U.S. 145 (1878) (upholding Utah's ban on bigamy); Bowers v. Hardwick, 478 U.S. 186, 189 (1986) (upholding Georgia's ban on sodomy as applied to homosexual men); CAL. CIv. CODE $\S 4101$ (West 1991) (setting forth minimum age of consent for marriage); CAL. PEN. Code $\S 261.5$ (West 1991) (setting statutory rape age); see also A. JAMES Reichley, Religion iN AMERICAN PUblic Life 120-22 (1985) (discussing Reynolds and related cases). 
parent to send a child to secondary school ${ }^{36}$ or the pledging of allegiance to the flag ${ }^{37}$ when those practices conflict with an individual's rights of conscience. And the state cannot coinpel participation in rehgious worship. ${ }^{38}$

\section{B. Religious Identity of Immigrants}

Just as there are strong pressures on immigrants to assimilate, there are equally compelling forces that keep immigrants apart from larger society. Immigrants hold on to their home culture in part because they find security in the familiar ${ }^{39}$ and in part because they are not able to find a home easily in the new society-a society often hostile to foreigners. ${ }^{40}$ The need to gravitate toward those who share natural bonds of land, langnage, or religion-to find a safe harbor among the unfamiliar-is a need for self-identification. This need for self-identification, which arises from "the identity crises that are endemic to emigration," 41 has been called "a visceral human instinct." 42

Describing the American immigrant experience, Professor Herberg explained that once in America, the characteristics by which one customarily identified oneself in the old country ${ }^{43}$ became invalid and often the ouly bond one could hope to find with another was a common language. Driven by this new linguistic grouping, a national-ethnic identity arose. ${ }^{44}$ Through the church organization, which was structured along linguistic lines so that all could understand the services, group identity thus evolved into common religious, lingunistic, and cultural (that is, national) heritage. $^{45}$ It is difficult for immigrants to assimilate, however, while retaiming their home language, culture, or manner of hiving. Religion, on

36. Wisconsin v. Yoder, 406 U.S. 205, 234 (1972).

37. West Virginia State Bd. of Educ. v. Barnette, 319 U.S. 624 (1943).

38. County of Allegheny v. ACLU, 492 U.S. 573, 660-61 (1989) (Kennedy, J., concurring in part and dissenting in part) (citing cases that prohibit government from compelling participation or attendance at religious activities).

39. See Herberg, supra note 21, at 28; see also Ronald L. Johnstone, Religion AND SOCIETY IN INTERACTION: THe Sociology OF RELIGION 267 (1975).

40. See, e.g., GoRDON, supra note 12 , at 92 (noting religious, economic, and political fears about "foreigners"); see also C. Bezalel Sherman, The Jew Within AMerican Society: A STUDY IN ETHNIC INDIVIDUALITY 141-48 (1965) (illustrating religious, ethnic, and national prejudices against Jewish immigrants).

41. RAymond B. Williams, Religions of IMMigrants FROM INDIA AND Pakistan 278 (1988).

42. Leroy S. Rouner, To Be at Home: Civil Religion as Common Bond, in CiviL Religion AND Political Theology 125, 125 (Leroy S. Rouner ed., 1986).

43. One example was the village of one's birth. Herberg, supra note 21, at 24.

44. Id. at 25-26.

45. Id. at 27; see also WILLIAMS, supra note 41, at 32-35 (the same processes are taking place today with respect to newer immigrant groups from India). Williams acknowledged the possibility of religious identification for Indians analogous to that seen by Herberg for Europeans, id. at 280, and identified typical patterns of formal religious ceremony nonattendance in the second generation, id. at 288. 
the other hand, is clearly one cultural element that immigrants are not expected to change in order to conform with any American norm.

[T]he perpetuation of ethnic differences in any serious way is altogether out of line with the logic of American reality. The newcomer is expected to change many things about him[self] as he becomes American-nationality, language, culture. One thing, however, he is not expeeted to change-and that is his religion. And so it is religion that with the third generation has become the differentiating element and the context of selfidentification and social location. ${ }^{46}$

Not only is rehion an acceptable means through which to carve out self-identity in American society but, given the alternatives, it may be the only possibility. ${ }^{47}$

In the United States, rehigion is the social category with clearest meaning and acceptance im the host society, so the emphasis on religious affiliation and identity is one of the strategies that allows the immigrant to maintain self-identity while simultaneously acquiring community acceptance. . . . Apart from its spiritual dimension, rehigion is a major force in social participation; it develops and at the same time sacralizes one's self-identity, and thus the rehigious bond is one of the strongest social ties. ${ }^{48}$

Under the First Amendinent, Americans of every religious background are guaranteed the same freedoms. The Supreme Court summarized this ideal when Justice Stevens wrote for the majority in Wallace $v$. Jaffree $:^{49}$

[T] he individual's freedoin to choose his own creed is the counterpart of his right to refrain from accepting the creed established by the majority. At one time it was thought that this right merely proscribed the preference of one Christian sect over another, but would not require equal respect for the conscience of the infidel, the atheist, or the adherent of a non-Christian faith such as Islam or Judaism. But when the underlying principle has been exainimed in the crucible of litigation, the Court has unambiguously concluded that the individual freedom of conscience protected by the First Amendinent embraces the right to select any religious faith or none at all. ${ }^{50}$

First Amendment freedoms are important to iminigrants for the same reasons they are important to other Americans. But to the immigrant

46. HERBERG, supra note 21 , at 35 .

47. Cf. WILliamS, supra note 41, at 27 (elements important to Indian immigrants as stated in ETHNIC GROUPS AND BOUNDARIES: The SOCIAL ORGANIZATION OF CULTURE DifFERENCE 33-34 (Fredrik Barth ed., 1969)). The elements of identity listed as possible choices for Indian immigrants were tribe, caste, language group, region, and state. Williams added religion to this list. Perhaps only in the early stages of immigration, through which many Indians are now passing, can factors other than religion play a serious role in forming group identity.

48. Id. at 11-12 (experience of Indian immigrants in America). But cf. JoHNSTONE, supra note 39, at 145 (labor unions, fraternal lodges, newcomers' clubs, and political parties also provide group identification).

49. 472 U.S. 38 (1985).

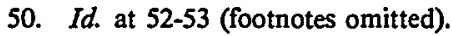


the Establishment Clause means more than freedom of worship-it means freedom to develop one's own rehigious identity and to share a community and identity with one's family and one's people.

\section{II}

\section{Comparison of Ritual Across Religions}

This Part discusses what constitutes religious identity through a comparative analysis of how ritual and symbolism function in different religions and cultural traditions. The differing roles of ritual and symbolism provide the starkest contrasts between Christianity-the religious context familiar to most Americans-and Judaism, Islam, and other religions. While Christian tradition focuses on "belief" as the major religious criterion, other traditions place much more empliasis on ritual. Therefore, a Supreme Court focus on belief as the value that the First Amendment protects will inevitably leave these minority rehgions without the protection of the First Amendment and underestimate the effect of exposing non-Christian children to Christian rituals im public school Christmas observances.

\section{A. Religion as Transmitter of Social Identity}

While it is understandable that religion came to be the unifying cultural force among religious immigrants in America, it may be surprising to discover that rehigion can serve the same self-locating function for those immigrants who never considered themselves religious in their homelands. ${ }^{51}$ If religion is, for many people, "more than commitment to a set of religious beliefs, symbols, and rituals," 52 for many it also is less; religion can serve instead primarily as a means of identifying with one's group.

Professor Kent Greenawalt, in attempting to develop a useful way to analyze what is and is not religion for purposes of the First Amendinent, ${ }^{53}$ identified various elements of the "indisputably religious":

[A] belief in God; a comprehensive view of the world and human purposes; a belief in some form of afterlife; communication with God through ritual acts of worship and through corporate and individual prayer; a particular perspective on moral obligations derived from a moral code or from a conception of God's nature; practices involving repentance and forgiveness of sins; "religious" feelings of awe, guilt, and adoration; the use of sacred texts; and organization to facilitate the cor-

51. See Williams, supra note 41 , at 11 ; see also JoHNSTONE, supra note 39 , at 267.

52. JoHNSTONE, supra note 39 , at 267.

53. Greenawalt avoids the suggestion that he or anyone can offer a useful "definition" of religion. See Kent Greenawalt, Religion as a Concept in Constitutional Law, 72 CALIF. L. REv. 753, 762-64 (1984). 
porate aspects of religious practice and to promote and perpetuate beliefs and practices. ${ }^{54}$

Greenawalt acknowledged that none of these elements is indispensable to religion, including behef in god, and that the hist could be expanded or organized differently. ${ }^{55}$ By neglecting to mention ritual behavior other than worship, Greenawalt revealed Christian bias. Non-Christians often find their most significant rehgious expression in ritual forms other than those listed.

American Jews are the most familiar example of a group that expresses its religious identification primarily in nontlieistic terms through adlierence to religious symbols and rituals. Although identification among Jews has been growing in importance, the rehgious aspect of Jewisl ritual has been reduced largely to insignificance. ${ }^{56}$ Morton Rosenstock observed of American Jews that their rehgion is usually lacking in personal faith and traditional practice; fundainental, however, are group identification and loyalty. ${ }^{57}$ Modern American Jewish religion has been called "symbolic Judaism" because it einphasizes itens of nostalgic cultural value (for example, Yiddisl words, Jewish objects, and selective religious rituals) that "help socialize the clildren into an awareness of and affection for their Jewish identity."58 Indeed, Hanukkalı has grown from a holiday of minor importance to a major means of expressing that Jewish identity durmg the time of year in which Christmas is so prominent. $^{59}$ The persistence of kashruth (Jewish dietary law), ${ }^{60}$ even in token form, is more a testament to the special significance of these rules in expressing Jewish apartness than to some basic level of orthodox belief. ${ }^{61}$

54. Id. at 767-68.

55. Id. at 768.

56. See Herberg, supra note 21, at 205-12; see also Peter W. Williams, America's Religions: TRADitions aNd CULTURES 19-25 (1990) ("[T]o be a good Jew is not primarily to believe the correct ideas, but to do the correct things." Id. at 19.).

57. Morton Rosenstock, The Jews: From the Ghettos of Europe to the Suburbs of the United States, in IMMIGRANT EXPERIENCE IN AMERICA 158 (Frank J. Coppa \& Thomas J. Curran eds., 1976).

58. GORDON, supra note 12, at 194 (citing Herbert J. Gans, American Jewry: Present and Future, 21 COMMENTARY 422-30 (1956)).

59. Mae S. Rockland, The HaNukKah Book x-xi (1975).

60. "Kosher" is the adjective describing food prepared according to these dietary rules.

61. See, e.g., Huston SMITH, THE WORLD's RELIGIONS 300 (1991) ("Jews are united more by what they do than by what they think."); WILLIAMS, supra note 56, at 19-25 (contrasting Judaism as a way of life against Judaism as a belief system); see also MARY Douglas, NATURAL SYMBOLS: EXPLORATIONS IN COSMOLOGY 38-41 (1970) (noting nontheistic aspect of Jewish ritual); Marshall SKLARE, America's Jews 111-17 (1971) (discussing nonreligious reasons for Jewish observance, identifying criteria to explain why certain rituals are kept and others discarded, and noting the trend in American Jewish practice of downgrading sacramentalism and upgrading moralism).

Evidence of Jewish ritual-as-religion is common, not simply because Judaism is the nonChristian religion with which Americans have the most experience, but primarily because Jewish writers have provided a wealth of written resources on the Jewish experience in America and the enigma of Jewish identity. Cf. WILLIAMs, supra note 56, at 368 ("The separability of these 
Judaism is not the only rehigion whose primary expression is through ritual rather than faith. Islam is also defined in terms of ritual. A Mushim is not one who believes certain ultimate trutlis but ratlier one who keeps the five sacred practices (or pillars) of Islam: recitation of the La ilaha; praying toward Mecca five times daily; giving of alms; keeping the fast durimg Ramadan; and making the hajj to Mecca at least once during one's lifetime. ${ }^{6 \overline{2}}$

Existing sociological evidence suggests that ${ }^{-J}$ ews and Muslims are also not the only minorities for whom religious rituals serve to form group identity, especially for children. For example, Professor Raymond Williams' work with immigrant Indian families indicated that the inain purpose of the extensive network of hoine rehgious-study groups among Hindus in the United States is to provide Hindu children with religious training, and thus with a Hindu identity-c"so they will not get lost in American society."63 For groups with fewer numbers, such as Jains, Sikhs, and Muslims, the need for rehgious identification is even greater. ${ }^{64}$

Zen Buddhisin is another exainple of a religion whose primary features do not resenble those of Christianity. Zen does not purport to proinote an ethical belief systein, a inoral practice, or a view of the "ultimate"; yet it is commonly accepted as a religion, and the Supreme Court has recognized it as such in dicta. ${ }^{65}$ According to Shunryu Suzuki, a Zen Buddhist inonk, Zen consists essentially of the practice of zazen-that is, ritual sitting and ineditation. ${ }^{66}$ "Zazen practice is the direct expression of our true nature. Strictly speaking, for a human being, there is no other practice than this practice; there is no otler way of life than this way of life."67 Zen does not envision the aclieveinent of any understanding of "God" as the goal of the ritual practice. "The inost important point in our practice is to have right or perfect effort. ... Our effort in our practice should be directed froin achievement to non-achievemnent."68 "If you think you will get something from practicing zazen, already you are

concepts-people, culture, religion-has been a perennial topic of debate among religious and secular Jews alike.").

62. 2 The World's Great Religions: Religions of The West 117-18 (1963); see also F.K. Khan Durrani, A Plan of Muslim Educatronal Reform 7-8 (2d enlarged ed. 1986) (criticizing western distinction between sacred and profane as arising from dualistic nature of Christianity and not applicable to Islam in which "everything that promotes life and contributes to the ... well being of men and nations is religious"); id. at 27 (when a child knows the practice of prayer, there is no wisdom in requiring the child also to learn the same thing intellectually; the average man needs only to know the practice).

63. Williams, supra note 41 , at 47 .

64. Id. at 63-102.

65. Torcaso v. Watkins, 367 U.S. 488, $495 \mathrm{n} .11$ (1961) (Maryland's requirement that a person profess a belief in God in order to qualify for the office of notary public violated the First and Fourteenth Amendments).

66. SHUNRYU SUZUKI, ZEN MIND, BEGINNER'S MIND 23 (1981).

67. Id.

68. Id. at 59 . 
involved in impure practice."69

How can a simple ritual, devoid of any exphicit connection to theism, faith, or morality, be thought of as rehigious? The answer is different for different religions. Joseph Campbell explained that western religions relate primarily to the umverse through the medium of ritual directed at a god. ${ }^{70}$ By contrast, eastern rehgions, such as Zen, view worship of gods as per se imsdirected. ${ }^{71}$ Campbell defined eastern religions, as well as all ancient rehgions, as "rehigions of identity," characterized by "mythic identification." In such traditions the ultimate goal of ritual practice is "the realization of one's own identity with this [ultimate] reality and recognition of its presence im all things."72 In western rehgions-"religions of relationship"-such an identity with the world is not possible, for the creator and the created are distinct. ${ }^{73}$ Within such a behief system, the human being is "related to" but not identified with god, ${ }^{\mathbf{7 4}}$ and the relationship arises only through birth into the group and through observance of the rituals of the covenant between man and god. In other words, the goal of ritual practice in these rehgions is to place worshippers within their religious group and to give them a religious identity. According to Campbell, "[n]o other ineans [of relating to god] are known or admitted to exist."75

Some sociologists have also theorized that rehgion is fundamentally a means of group identification. Emile Durkhein conceived of religion as the symbolic expression of a group's umity, ${ }^{76}$ as nothing more than society's norms, roles, and relationships expressed im another form. ${ }^{77} \mathrm{~W}$. Lloyd Warner, building on Durkheim's concept, found that behef in a sacred beimg is the symbolic form of the intense need to belong to something larger and more powerful than oneself and to incorporate a part of that within oneself. ${ }^{78}$ Ritual ceremonies, he argued, impress this social need upon people and make them aware of the existence of something beyond themselves which they behieve to be sacred. ${ }^{79}$ Yet that which is beyond the individual is "no more than the awareness on the part of mdividuals and the collectivity ... of their participation in a social

69. Id. at 60 .

70. See Joseph Campbell, The Secularization of the Sacred, in The Religious Situation: 1968, at 601, 609-14 (Donald R. Cutler ed., 1968).

71. See id. at 602 .

72. Id.

73. Id. at 609 .

74. Id. at 609-14.

75. Id. at 610.

76. Jonathon S. Woocher, SACred Survival: The Civil Religion of American Jews 13 (1986).

77. JoHNSTONE, supra note 39 , at $32,142-43$.

78. W. Lloyd Warner, An American Sacred Ceremony, in AMERICAN Civil Religion, supra note 32 , at $89,108-09$.

79. Id. at 109. 
group."80 That is, religion in its most basic form, even theistic religion, might ultimately best be understood as a form of group identification ${ }^{81}$ and religious rituals as the primary ineans of experiencing identity with the group.

Professor Milton Gordon explained why some adherents of theistic religions might be unaware of the role their religious practices play in transmitting social identity:

[A]ll of the major rehigious faiths-Jews, Catholics, and Protestantsoperate functionally so as to perpetuate ethnic communality in the general population. The Protestants are least aware of the process since their majority status and historical precedence in America tend to nuake then unaware of the Protestant assumptions and criteria operative in inany of the institutions which are labeled as "American" and "communitywide." 82

Even when rehigious rituals are generally devoid of any theistic component, functioning primarily to give adherents rehigious group identity, they can still be understood as primarily religious. Marshall Sklare postulated that the increase in Jewisl ritual observed anong families with young children could "be viewed in a sacred rather than a secular context, for in impressing on his child the importance of Jewish survival, the parent is involved in making an ultimate commitment." 83 Especially for people whose religions are closely identified with ethnicity (Jews and Himdus, for exainple), passing on one's identity to one's children, sharing with them one's only tangible connection with an irretrievable past extending back as far as the origins of the race or tribe, giving them rituals to help them place themselves at the hiving end of an eternity of human history-those endeavors are almost necessarily of a rehgious nature.

The function of religious ritual as a transmitter of social identity, rather than as a tool of religious indoctrinition, is underscored when rituals are perfornied in a language other than English. Even when rituals lave clear rehigious meaning in their original language, that meaning will be lost on children who speak only Enghish. Rather tlian attemptimg to explicitly translate tlie "rehigious" message, some religious leaders rely on the ritual acts themselves, without explanation, to communicate unarticulated messages to the children. ${ }^{84}$ The clearest message such unex-

80. Id. For an examination of the distinction between the secular and the sacred and an attempt to identify what remains sacred in modern culture, sec Huston Smith, Secularization and the Sacred: The Contemporary Scene, in The Religious Situation: 1968, supra note 70, at 583.

81. Cf. Williams, supra note 41 , at 47 (Hindu parents state that while they participate in religious groups to show devotion to God, they involve their children primarily to foster group identity).

82. GORDON, supra note 12 , at 241.

83. Marshall Sklare \& Joseph Greenblum, Jewish Identity on the Suburban Frontier 74 (2d ed. 1979).

84. WILliaMS, supra note 41 , at $286-87$. 
plained rituals can convey to the child is the message of belonging. Through the ritual experience children become a part of-identify with-the group with whom they share that experience, whether the immediate family or a larger religious or cultural group.

Often, however, Supreme Court decisions have demonstrated that rehigious practice is not protected by the First Amendment unless it shares stereotypical characteristics with the generally accepted religious practices of the Christian majority. ${ }^{85}$ Members of minority religionseven ancient, well-establislied rehigions with millions of adherents and widely recognized and verifiable rituals-are deprived of their equality and their constitutionally guaranteed religious freedom by such decisions. Constitutional rights are meaningless if not used to protect minorities from the tyranny of the majority, expressed in the guise of rules of " 'general apphicability." "86

\section{B. Teaching "Americanism": The Role of the Public Schools in Acculturation and Identity Formation}

The public schools are a powerful tool for imtroducing children to the dominant culture and assimilating them into it. ${ }^{87}$ While clinldren of the majority are presumably imdoctrinated into the doininant culture both mside and outside the home, immigrant parents, who may never fully adopt American language and culture, are not equipped to pass the new culture on to their children. The assimilation of immigrant children into the dominant culture must, therefore, take place outside the hoine: on the streets, with friends, and particularly in school. ${ }^{88}$

The public schools have been enormously successful in acculturating immigrant children and the children of immigrants. ${ }^{89}$ This acculturation is accomplished by bringing tliese children into an atınosphere of American national umty, enforced through the authority of the school

85. See, e.g., Department of Human Resources v. Smith, 494 U.S. 872 (1990) (denying Native American Church members who wished to use peyote for religious rituals an exemption from a criminal statute prohibiting its use); Goldman v. Weinberger, 475 U.S. 503 (1986) (refusing to grant an exemption under the Free Exercise Clause to an Orthodox Jew who wished to wear a yarmulke in violation of the military dress code, even though the code allowed the wearing of crosses, rings, and other symbols typical of Christian identity).

86. Smith, 494 U.S. at 879 (quoting United States v. Lee, 455 U.S. 252, 263 n.3 (1982) (Stevens, J., concurring in the judgment)).

87. See Richard L. Roe, Valuing Student Speech: The Work of the Schools as Conceptual Development, 79 CALIF. L. REV. 1271, 1276-92 (1991) (describing the judicial view of the mission of the schools as the "inculcation of values").

88. See Sherman, supra note 40 , at 30 (identifying the school as the most important institution for assimilating immigrant children into the dominant culture, and explaining school's effects on the psyches of immigrant children).

89. GoRDON, supra note 12 , at 244-45 (describing the extent to which second-generation immigrants are and will be acculturated and identifying public schools as one of the primary sources of acculturation). 
and through the peer group. ${ }^{90}$ In this environment children are given a second set of rituals with which to estabhish a group identity in addition to that being formed within the family and the parents' rehious groupchildren are taught the "religion of deinocracy" througl American history, social studies, and civics. ${ }^{91}$ "[W]hatever contest ensued between the beliavior inodels of the parents' culture and those of the general American society ... there was no question as to which would be the winner."92

Formal lessons are not the only way schools influence the beliavioral development of children. ${ }^{93}$ Children are also affected by more subtle experiences, including scliool celebration of holidays. Children probably gain some sense of the importance and meaning of a holiday from the length of time public schools are closed to celebrate that holiday. Whereas the commemoration of people like Lincoln and Washington, whom children study in their formal history and civics lessons, 1might together inerit only one coinbimed Presidents' Day holiday, ${ }^{94}$ Christinas usually commands a full two-week vacation. ${ }^{95}$ To the degree that vacation time is a ineasure of the cultural importance of a holday, school children are taught to hold Christmas in high regard.

Time off, lowever, is only one means by which society conveys to children the importance of a holiday. Halloween, St. Patrick's Day, and Valentime's Day are not typically marked by school closings; $^{96}$ yet the time and activity devoted to these holidays in the scliool curriculnm can be significant. Activities in anticipation of Christmas, such as theine art,

90. SHERMAN, supra note 40 , at 30-31. According to Sherman, two important assimilating tools of the public school are compulsory attendance and the creation of an atmosphere of national unity. By taking children out of the home for a significant portion of the day, compulsory attendance removes the child from the influence of the parents' culture. Id. at 30 . Further, im the atmosphere of national unity created by the schools, it becomes the patriotic duty of the child to speak English. Id. The sehoolchild is then immersed in a group of American children, where English is not only the language of instruction and of authority but is also an immediate necessity for communicating with one's peers. Especially in cities with significant non-English-speaking populations, children often come from diverse lingnistic backgrounds. English becomes the lingua franca of the new American child's multicultural world.

91. Herberg, supra note 32 (describing American political and social beliefs, including democratic idcals, as a "religion").

92. GoRDON, supra note 12, at 107 (describing how aceulturation weakened and eventually overpowered ties to previous culture and threatened immigrant family interactions).

93. See John F. Wilson, A Historian's Approach to Civil Religion, in AMERICAN CIvIL Religion, supra note 32, at 115, 130. Wilson noted Phillip Hammond's suggestion that it is not through formal teaching but through competitive sports, student elections, etc., that civil religion (Herberg's "religion of democracy") would be taught in public schools. Id. Wilson further noted that Hammond echoed J. Paul Williams' earlier view of the school as the primary institution for teaching "civil religion." Id.; see also Herberg, supra note 32, at 84 (articulating Williams' view that democracy is taught as religion).

94. Some school districts continue to honor both Lincoln and Washington on their traditional birthdays. See, e.g., 1991-92 Berkeley Unified School District Calendar (1991).

95. See, e.g., id.

96. See, e.g., id. 
music, storytelling, pageants, and plays, often occupy a significant amount of school time during November and December. School time devoted to holiday activities can be of greater influence than school closings because children might find no special meaning in school closings if, as witl weekends and summer vacation, the time off is not marked by special activities underscoring the holiday's significance. Because the significance of a looliday can be suggested by the amount of time and nuinber of activities devoted to its observance, what children learn by observing a loliday such as Christmas is of soine consequence.

Common patterns of holiday observance im schools incorporate a wide array of traditional activities, mcluding symbolic objects, colors, foods, and myth-like stories. ${ }^{97}$ Many of the activities try to draw connections between scliool and home observances. For example, students might be asked to make objects in school that can be used in home celebrations (such as Christmas tree ornaments), to talk about what they will be doing at lome during Christmas, or to share their Christmas gifts with the class after the lioliday season is over. Most schools are careful not to celebrate Christmas witll an explicitly theistic message because of the obvious constitutional implications. ${ }^{98}$ But even ritual observances that are intended to be secular can serve a rehgious function, and thus raise constitutional concerns in the public school context.

Of course, nonreligious holidays can also involve ritual and symbolism that lead individuals to identify with a larger group. Warner's exammation of Memorial Day rites in a small town suggested that such civil ceremomies "are rituals of a sacred symbol system which functions periodically to unify the wliole community."99 Scliool celebration of Christmas could argnably operate in a similar fashion by advancing children in a secular way imto the larger society. ${ }^{100}$ The question, then, is whether Christmas observances in the pubhic scliools draw children into society on a purely secular level or whether they also or primarily operate on a religious level. The next Section addresses that question.

\section{Observance of Christmas in the Public Elementary Schools as Religious Indoctrination}

In American society, as perhaps in any secular society, religious and nonreligious training are usually allocated to separate institutions.

97. See generally George W. Douglas, The AmericaN Book of Days (1948) (description of American holiday observances, chronologically by day).

98. Lattin, supra note 3, at A12 (noting total lack of religious reference in school holiday celebrations).

99. Warner, supra note 78, at 91 (discussing how Memorial Day celebrations have many of the same characteristics and serve many of the same functions as religious rituals).

100. Cf. Greenawalt, supra note 53, at 768 (questioning whether any of several identified elements of religion are "sufficient" to make something religious because many of the same features of religion have "nonreligious manifestations"). 
Fusion of religious and nonreligious education is inappropriate unless a society is unitary and its members share common group identity, institutions, and values. For exainple, in societies not self-consciously secular, children's upbringing can consist almost entirely of their religious upbringing, "and any question of the relation between religion and education would not [nake] sense."101

But education, whether rehigious or nonrehgious, is not confined to formal institutional means. It also takes place informally through conversation, the retelling of inyths and stories, and observation of and participation in ritual practices. In primitive societies all socialization, including religious socialization, is achieved this way. ${ }^{102}$ This same informal religious socialization goes on all around American children, despite the official separation of rehigious and general education. ${ }^{103}$

Infornal socialization continues even inside the schoolhouse door. Whether or not children are formally instructed in religion, inodern school holiday observances are likely to socialize on the informal level. For exainple, a teacher probably would not give a formal lesson on why children should decorate Christinas trees or instruct children on the feelings and expectations they should develop at Christinastime, but might have children inake Christinas decorations or read a Christinas story.

Of course, whether children will understand the ineaning of school holiday observances like Christmas as religious or secular is difficult to determine. But a child need not be conscious of the religious nature of a ritual for that ritual to instill religious identification in the child. Like Jewisl and Hindu holiday observances, Christian rituals need not contain a theistic component to perform a religious function. ${ }^{104}$ Young children learn their religious identity prinarily through informal ineans. Only later do children supplenent their socialization througl formal cognitive learning. ${ }^{105}$ Thus, although children are capable of observing and emulating the rituals associated with inature religious belief from an early age, it is not until later in their developinent that they are able to fully appreciate the role and purpose, or even the existence, of religious

101. Harvey G. Cox, The Relationship Between Religion and Education, in RELIGION AND Public Education 99, 99 (Theodore R. Sizer ed., 1967) (discussing the relationship between religious and educational institutions, and identifying the theological and pedagogical issues that arise where these institutions intersect).

102. JOHNSTONE, supra note 39 , at 78 . Some people believe that primitive man more closely perceived the original meanings of his rituals and symbols and that we have forgotten the meanings through the ages; but this might not be so. It is a modern imnovation to analyze our cultural symbols; ancient man simply lived them. See CARL G. JUNG, Approaching the Unconscious, in MAN AND HIS SYMBOLs 81 (1964) (discussing the origin of and basis for symbolic rituals like Christmas).

103. Johnstone, supra note 39 , at 78,80 (informal socialization remains important in industrialized society).

104. See WiLliaMs, supra note 41 , at 287 (concerning foreign language rituals). Rituals in a tongue the children do not understand cannot carry any explicit message. Cf. supra text accompanying note 63 (discussing the function served by Hindu religious study groups).

105. JOHNSTONE, supra note 39 , at 89. 
beliefs. ${ }^{106}$

Dr. Carl Jung has observed that even many adult participants in rehigious rituals do not consciously understand the symbolic meaning of the rituals:

You may ask many civilized people in vain for the real meaning of the Christinas tree or of the Easter egg. The fact is they do things without knowing why they do them. I am inclined to the view that things were generally done first and that it was only a long time afterward that somebody asked why they were done. ${ }^{107}$

Despite the fact that children and even many adults might not recognize the religious significance of Christmas rituals, the idea that Christmas has a primarily secular meaning is difficult for non-Christians to accept. Certainly participants and nonparticipants are usually distinguished along rehigious limes. ${ }^{108}$ Children learn their nominal rehious identity from an early age. ${ }^{109}$ As they learn the Christmas ritual, they discover it to be something that differentiates the labels "Mushm" and "Jew" from "Catholic" and "Protestant." To a child, a "Christian" is one who celebrates Christmas, while a "Jew" or "Muslim" does not.

Justicc O'Connor has suggested that Christmas is both secnlar and religious. ${ }^{110}$ Assuming this were true, the public schools could in theory ensure that children be exposed only to the secular, not the rehious aspects of Christnıas. But to a child just beginning to develop a religious identity, this distimction between secular and religious has no meaning. Some scholars liave found that "[t]he young child tends to confuse rehgious identity with nationality and racial designations."111 Children are only beginning to develop the means to classify their knowledge; the Christmas ritual will be just one among many lessons learned formally and informally at school, on a par with spelling and aritlimetic lessons, rules of personal liygiene, playground manners, and lunch-line decorum.

The child's mability to distinguish between the "secular" and the

106. Id. at 90.

107. JUNG, supra note 102, at 76 (discussing how people often participate in symbolic rituals without understanding the content of ideas conveyed or represented by those rituals).

108. It is true that Jehovah's Witnesses and some other Christian groups do not observe Christmas. Early Christians did not celebrate Christmas, condemning observance of all birthdays as a repugnant, heathen custom. Douglas, supra note 97 , at 626 . It is only fair to note that some acculturated Jews, on the other hand, do celebrate Christmas. $C f$. id. at 632-33 (as to why Jews should celebrate Christmas). Still, it seems that the common reaction to being told that someone does not celebrate Christmas is to conclude that the person is Jewish. Yet if Christmas were a secular "American" holiday the more natural reaction would be to conclude that the person is a foreigner.

109. See Johnstone, supra note 39, at 90 (citing David Elkind, Age Changes in the Meaning of Religious Identity, in REVIEW OF RELIGIOUS RESEARCH 6, 34-40 (1964)).

110. County of Allegheny v. ACLU, 492 U.S. 573, 633-35 (1989) (O'Connor, J., concurring in part and in the judgment).

111. JohnSTONE, supra note 39, at 78 (citing David Elkind, Age Changes in the Meaning of Religious Identity, in REVIEW OF RELIGIOUS RESEARCH 6 (1964)). 
"religious" aspects of Christmas is compounded by the fact that the child's mind, searching consciously or unconsciously for the meaning of Christmas rituals, will not be limited to the controlled "secular" context of the school celebration. Children will try to glean meaning from whatever sources their surroundings offer. In searching for the symbolic meanimg of rituals, children are not sent alone into a barren wilderness. Rather, they are released every day into a world im whicli only government actors are constrained by the First Amendment; the Constitution does not limit private actors to a secular presentation of Christmas. Children searching for the meaning of Christmas will have no trouble discovering a rehgious inessage that has been carried worldwide for nearly two thousand years. The ritual is emblazoned on stamps ${ }^{112}$ and repeated in television and radio advertisements, "news" stories, broadcasts of midmight mass, and the lyrics of ubiquitous Christmas hymns; ${ }^{13}$ it is on storefronts, private lawns, churchyards-even im public parks and on the courthouse steps. ${ }^{114}$

The difficulty in separating the "secular" and "religious" aspects of Christmas is not limited to children, lowever. Suggesting tliat Christmas is botli secular and rehgious is tantamount to suggesting that prayer is both secular and religious. Prayer might imvolve going to a particular building, reading from certain prescribed texts, eating and drinking particular substances, and mouthing certain formulaic utterances-all actions having secular purposes as well. ${ }^{115}$ In the context of the religious purpose of supplication to a god, however, the acts are raised to religious significance. Similarly, the rehgious nature of religious liymns might be

112. During the Christmas season, the Postal Service often issues Christmas stamps bearing religious paintings. The Court has noted that religious paintings are unobjectionable in a museum setting. See, e.g., Lynch v. Donnelly, 465 U.S. 668, 692 (1984) (O'Connor, J., concurring). But the Christmas season is not a secular context-art might be honored at any time of year but the Postal Service does not choose to honor religious paintings at all times of the year. At Christmastime the secular excuse is unconvincing.

113. Consider Christmas television programming. The Christmas episode of nearly every weekly television series, whether or not directed at children, revolves around the idea of Santa Claus. Often a hfelong disbeliever is converted or characters overcome with doubt and cynicism from the previous eleven months have their faith restored through "witnessing" what every grownup knows to be impossible. Cf. Charles Dickens, A Christmas Carol (1843) ("Bah! Humbug!"-type sees the light and discovers how wonderful Christmas really is); DR. SEuss, How The GRiNCH STOLE Christmas (1967) (same). Writers and producers, and many viewers, might feel that these programs present a secular Christmas theme that all should find simply heartwarming; yet the retelling of these popular Christmas myths is hardly secular. Perhaps presentation of Christ's miraculous conception would be inappropriate in the popular media; however, the magical feats of Santa-squeezing his immense jolliness through millions of impossibly skinny chimneys on a single night-is no less miraculous. The unmistakable effect is to evoke thoughts of the religious miracle and message of Jesus Christ, forsaken by the harried and jaded, and to rephrase Christ's brotherly love in the quotidian terms of Santa's holday gift-giving spirit.

114. See County of Allegheny v. ACLU, 492 U.S. 573 (1989) (display on courthouse steps); Lynch, 465 U.S. at 668 (park display).

115. For example, this litany could just as easily describe eating out. 
thought to reside in their words; but that does not mean that one can separate the lyrics from the tune and thereby create one religious and one secular song, or that the church organist is somehow involved in a secular act while the choir is involved in a religious one. Ultimately, Christmas rituals can only be reasonably understood as religious because sucl rituals can never be truly divorced from the broader religious context in which they arose.

Cultural rites operate to express cultural meaning. Through their syinbols they tell participants and observers about society and about the role of ineinbers within that society. ${ }^{116}$ When public schools observe Christmas, they give children a rich repertoire of deeply symbolic language. Christmas celebrants might becoine so accustomed to this symbolisin that they no longer register the holiday as religious and are unaware of any conscious impact of the holiday's language and syınbols. "Yet symbols which are tenaciously adlered to can hardly be dismissed as altogetler meaningless. They must mean soinething. ... Symbols are the only means of communication. They are the only means of expressing value; the inain instruments of thought, the only regulators of experience."117

Justice Brennan acknowledged in his Allegheny concurrence that inere objects can carry religious meaning depending on the context. ${ }^{118}$ Although many coinnentators agree that it is nearly impossible to arrive at a useful definition of the term "religion" for constitutional purposes, ${ }^{119}$ Justice Brennan attempted to develop a working definition of "religious symbol." He said that the First Amendment prohibits government "display of an object that 'retains a specifically Cliristian [or other] religious meaming." "120 $\mathrm{He}$ thus acknowledged the religious roots of "secular" holidays by finding that inere objects can be infected witl religious significance. ${ }^{121}$ Professor Greenawalt also recognized this principle by noting

116. Cf. DougLAS, supra note 61 , at 38 ("For communication about religion to take place, the structure of the symbols must be able to express something relevant to the social order.").

117. Id. at 37-38. Douglas explained that the meaning of ritual should not be underestimatcd"empty" rituals are not perpetuated. Id. at 37. As I have argued, the meaning of, for example, Friday abstinence for Catholics, or kashruth for Jews, is that of "belonging," See generally Christopher I. EJizU, Ofo: IGbo RITUAL Symbol 1-10 (1986) (definition and importance of symbols, especially religious symbols, and their operation on various levels of consciousness); JUNG, supra note 102 (origins of symbohic ritual and the significance of Christmas rituals in particular).

118. County of Allegheny v. ACLU, 492 U.S. 573, 639 (1989) (Brennan, J., concurring in part and dissenting in part).

119. See, e.g, Greenawalt, supra note 53 , at 763 ("'A]ny dictionary approach oversimplifies the concept of religion, and the very phrase 'definition of religion' is potentially misleading.").

120. Allegheny, 492 U.S. at 637 (1989) (Brennan, J., concurring in part and dissenting in part) (quoting Lynch v. Donnelly, 465 U.S. 668, 708 (1984) (Brennan, J., dissenting)).

121. See id. at 639-40. Justice Brennan differed with Justice O'Connor and others who saw holiday symbols as "necessarily secular," pointing out that Justice O'Connor could only find that the Christmas tree and menorah presented a permissible message of religious freedom by concluding that both the Christmas tree and menorah were religious symbols. Id. If the tree had really been 
that history can operate in two directions-either robbing symbols of religious significance or instilling it in them. "If everyone has come to regard Santa Claus as a nonreligious symbol, the government's [display of him] would not be religious. On the other hand, if everyone thought seriously of Santa Claus as a Christian saint ... the government's acts would support religion."122

As long as Christmas rituals are allowed in the schools, soine children will be torn by competing loyalties. In the classroom and among school friends, the celebration of Christmas is the normal and expected custom; it becomes integrated with the basic school curriculum, like reading and writing. The process of self-identification becomes inore coinplicated for children when the rituals and symbotisin taught to them in the classroom, and informally reinforced in the surrounding society, are unlike those of their parents. While non-Christian parents present the message that December 25th is indistinguishable froin other days, non-Christian children feel pressure to embrace Christmas celebrations as their own in order to achieve full assimilation into American society. Ultimately, children are left to their own devices in filtering the different and sometimes conflicting messages about religious identity learned at loone, in school, and through observation of the world at large.

\section{III}

\section{Supreme Court Establishment Clause JURISPRUDENCE: KEEPING RELIGIOUS OBSERVANCE OUTSIDE THE SCHOOLS}

In the previous Parts, $I$ argued that religion can play a central role in an individual's searcli for identity and that religion is not only about faith but also about symbols, practices, and rituals. ${ }^{123}$ Witll these under-

secular, the display's message would not have been one of religious plurality but only an endorsement of Judaism. Id.

122. Greenawalt, supra note 53, at 794 (discussing what should be the constitutional status of symbols that arguably have religious and secular content).

123. One characteristic feature to note in all First Amendment religion cases, whether under the Free Exercise or the Establishment Clause, is that no one seems to know just what "religion" is. The Court has occasionally been willing to classify certain activities as being religious. For example, classroom prayer qualifies. See Engel v. Vitale, 370 U.S. 421, 424-25 (1962) ("It is a solemn avowal of divine faith and supplication for the blessings of the Almighty. The nature of such a prayer has always been religious ...."). Reading and posting the Bible qualifies. School Dist. v. Schempp, 374 U.S. 203, 224 (1963) (Bible inarguably an instrument of religion, used in this case for a religious purpose); see also Stone v. Graham, 449 U.S. 39, 41 (1980) (per curiam) ("The Ten Commandments are undeniably a sacred text in the Jewish and Christian faiths, and no legislative recitation of a supposed secular purpose can blind us to that fact.").

At times the Court has even becn willing to say what definitely cannot be classified as religion. For example, the Court has stated that government actions such as using the words "God save the United States and this honorable court" to open Court sessions and declaring Thanksgiving a public holiday are "the only ways reasonably possible in our culture ... of solemnizing public occasions." Lynch, 465 U.S. at 693 (O'Connor, J., concurring). But there has never been a serious attempt to 
lying values and concepts in mind, I now turn to Supreme Court First Amendment jurisprudence to test the constitutional validity of public elementary school Christmas holiday observances. I start by discussing the historical background of the Supreme Court's treatment of rehion in general and in the public schools in particular. I then consider the five modern Establishment Clause approaches to church-state interactionsthe Lemon test's purpose, effect, and entanglement branches, Justice O'Connor's endorsement test, and Justice Kennedy's coercion test-in the context of public school Christmas observances. Such observances fail to pass constitutional muster under any of these approaches because they amount to state-supported rehgious indoctrination, which is forbidden by the First Amendment.

\section{A. The Problem of Church, State, and School}

The history of rehgious freedom in the United States has been one of struggle by religious minorities to share in the rights guaranteed by the First Amendment. Originally, the First Amendment functioned primarily to protect Protestants from the imposition at a national level of particular practices of competing sects ${ }^{124}$ and only later, as Catholic immigrants streamed into the country, gradually recogirized the religious rights of non-Protestants. ${ }^{125}$ While many of the inost egregious examples

define religion in the cases. Nor should such an attempt necessarily be made, for it is not at all obvious that religion could ever be successfully defined. See Greenawalt, supra note 53, at 762-69 (1984). Greenawalt avoids, and would help courts avoid, having to offer an explicit definition of "rehigion" by using an analogical approach: defining what is religious in any given case by analogy to the indisputably religious. Id.

For purposes of this Comment, it is not necessary to define religion any more precisely than has already been done in the cases. Part II has, however, atteinpted to expand the reader's current understanding of the "indisputably religious" to include the use of well-known religious symbols and rituals to bring children into the religious group by inculcating in those children religious group identity.

124. Nine of the original colonies had state-established religions. James E. Wood, Jr., New Religions and the First Amendment, in ReLigion AND tHE STATE 185, 188 (James E. Wood, Jr. ed., 1985). These establishments soon began to give way under the pressures of a growingly diverse population. Neil C. McCluskey, The New Secularity and the Requirements of Pluralism, in Religion AND Public Education, supra note 101, at 231, 234 (discussing secularization of schools and the attendant reduction in the infiuence of previously doininant sectarian Protestant idcas). Virgima, for example, ended its church establishment soon after the American Revolution, while Connecticut, New Hampshire, and Massachusetts waited until 1818, 1819, and 1933, respectively. In inany states, the established religion was replaced by multiple establishments. See R. Freeman Butts, The american Tradition in Religion and Education $20-38$ (1950) (discussing establishment of religion in the colonies and the formation of multiple establishments); see also Engel, 370 U.S. at 428 n.10 (discussing colonies' varied approaches to established religion).

125. The gradual decline of Protestant control over the public schools is reflected in state court decisions and constitutions and statutes adopted during the nineteenth century and into the twentieth. One of the inost important cases was a decision of the Ohio Supreme Court upholding Cincinnati's prohibition of religious instruction and Bible-reading. BuTTS, supra note 124, at 138 \& n.37 (citing Board of Educ. v. Minor, 23 Ohio St. 211 (1872)); see also School Dist. v. Schempp, 374 U.S. 203, $272-75$ (1963) (Brennan, J., concurring); 2 ANSON P. STOKES, ChURCh AND STATE IN THE UNITED STATES 488-500 (1950) (giving text of seven state constitutional provisions prohibiting 
of state-imposed Protestant and Christian sectarianism in the schools have been gradually eliminated, ${ }^{126}$ a strong core bias in favor of Christiarnity has been left behind. Many immigrants to America today face state-sponsored antagomism to tlieir rehgious beliefs because they are not Christians-tliey are Mushins, Sikhs, Hindus, Buddhists, and Jews, to name just a few rehigious groups. To these people, a religious freedom conceived of as the freedom to practice any form of Christianity whatsoever is really no freedom at all. This Section looks at the background to testing the constitutionality of public elementary scliool Christmas holiday observances, emphasizing the special circumstances of children compelled to attend the public schools and there be indoctrimated with the state's values and beliefs-including religious values and beliefs that Christian Americans do not seem to be able to regard as religious at all.

Such religious values and beliefs, instilled im public scliool children in the guise of holiday celebrations, offend the religious beliefs of nonChristians even thougl1 as Christian traditions tliey might have lost mucl1 of their rehigious import for Christians. By observing the Cliristian rituals of Christınas, even without any theistic message, scliools pass on to cliildren a Christian tradition just as mucli as Jews and Hindus pass their traditions on to their children through loliday celebrations. ${ }^{127}$

aid to sectarian schools and various laws goveruing religious instruction in public schools); James $\mathrm{E}$. Wood, Jr., Religion and Education in American Church-State Relations, in Religion, THE STATE AND EDuCATION 25, 30 (James E. Wood, Jr. ed., 1984) ("[B]y the 1870s most state constitutions expressly divorced religion from the public educational system and state courts widely espoused church-state separation for the public school."). In 1910 the Illinois Supreme Court ruled that reading the King James Bible and reciting the Protestant version of the Lord's Prayer in school was forbidden by the Illinois Constitution. ReICHLEY, supra note 35, at 146; cf. Knowlton v. Baumhaver, 166 N.W. 202 (Iowa 1918) ("well settled" that taxes not to be used for religious instruction, particularly sectarian), cited in 2 STOKES, supra, at 69 n.228.

126. Originally the schools were sectarian extensions of the churches. DONALD E. Boles, ThE Bible, Religion, AND the Public Schools 4 (1963). Indeed, religious instruction was "one of the primary purposes for which schools were founded in the first place in the British colonies." REICHLEY, supra note 35, at 136. Educators believed the Bible to be the primary educational tool. BOLES, supra, at 7-10 (discussing textbooks used in colonial schools); see also 2 STOKES, supra note 125, at 52 (discussing the fundamental role that religious instruction played in Massachusetts schools). But reading from the King James Bible and reciting the Lord's Prayer daily were Protestant practices, unacceptable to Catholics. BOLES, supra, at 15-16, 23 (discussing the controversy in Massachusetts and elsewhere, after the passage of laws banning sectarian instruction in public schools, over whether Bible-reading is "sectarian"); BUTTS, supra note 124, at 118, 138 (discussing how Bible-reading seemed nonsectarian to Protestants but not to Catholics).

Sectarian Protestant teaching, and Christian prayer and practices in general, have been phased out gradually in the schools. See id. at 116-18 (discussing the early development of nonsectarian schools); 2 STOKES, supra note 125, at 50-61 (discussing the evolution of secularized education in Massachusetts and Connecticut in particular); cf. 1827 Laws of Mass., ch. 143, $\S 7$ (Massachusetts law banning sectarian texts), cited in Burrs, supra note 124, at 131 n.24; REICHLEY, supra note 35, at 137 (discussing the withdrawal of state support for religious instruction as the population became more diverse). More recently, the Supreme Court's decisions in Engel v. Vitale, 370 U.S. 421 (1962), and School District v. Schempp, 374 U.S. 203 (1963), officially inade seetarian practices in public schools illegal in all states.

127. See supra note 104 and accompanying text. 
In the development of freedom-of-religion jurisprudence, the Supreme Court has been keenly aware of the precarious situation of schoolchildren who are compelled by the state to tolerate whatever messages the state wishes to communicate in its schools. The Court's concern for protectimg impressionable young minds has its roots in the earliest First Amendment cases, mcluding tlose not directly mterpreting the Establishment Clause. ${ }^{128}$ It ecloes concerns of the founding fathers ${ }^{129}$-concerns that lave been re-echoed in university, ${ }^{130}$ public scliool, ${ }^{131}$ parochial school, ${ }^{132}$ and even nonschool Establishment Clause cases, ${ }^{133}$ irrespective of outcome. Justice Brennan, writing for the Court in Edwards v. Aguillard, ${ }^{134}$ summarized this line of dicta: "Students in [the public schools] are impressionable and their attendance is involuntary. The State exerts great authority and coercive power through mandatory attendance requirenients, and because of the students' eniulation of teacliers as role models and the children's susceptibility to peer pressure."135

Sinilarly, in lis concurrence in School District v. Schempp, Justice Brennan explicitly recognized the difference between young cliildren and

128. See, e.g., West Virginia State Bd. of Educ. v. Barnette, 319 U.S. 624, 637 (1943) (unconstitutional to compel children in public schools to salute flag and recite pledge of allegiance). The Court observed: "That [states] are educating the young for citizenship is reason for scrupulous protection of Constitutional freedoms of the individual, if we are not to strangle the free mind at its source and teach youth to discount important principles of our government as mere platitudes." Id.

129. See School Dist. v. Schempp, 374 U.S. 203, 235 (Brennan, J., concurring) (quoting Thomas Jefferson's admonition against "putting the Bible and Testament into the hands of the children at an age when their judgments are not sufficiently inatured for religious inquiries," 2 WRITINGS of THOMAS JEFFERSON 204 (memorial ed. 1903)).

130. See, e.g., Tilton v. Richardson, 403 U.S. 672, 685-86 (1971) (contrasting church-related umiversity programs, characterized by academic freedom, with parochial elementary school programs, whose policy is to " "assure future adherents to a particular faith by having control of their total education at an early age," " and noting that "college students are less impressionable and less susceptible to religious indoctrination" (quoting Walz v. Tax Comm'n, 397 U.S. 664, 671 (1970))).

131. Edwards v. Aguillard, 482 U.S. 578, 584 (1987) (striking down a Louisiana statute that forbade teaching the theory of evolution in public schools unless accompanied by instruction in "crcation-science," and noting that students in public schools were impressionable and that the state could influence them due to attendance requirements, pupils' emulation of teachers, and peer pressure); Weisman v. Lee, 908 F.2d 1090, 1096 (1st Cir. 1990) (Bownes, J., concurring) (middleschool graduation benediction delivered by clergy and invoking a deity held to violate the Establishment Clause) ("Middle school students are at a very different stage in their development and relationship to prayers than state legislators."), aff'd, 112 S. Ct. 2649 (1992).

132. School Dist. v. Ball, 473 U.S. 373, 390 (1985) (striking down publicly flnanced programs that provided secular education to students in parochial school classrooms) ("The symbolism of a union between church and state is most likely to influence children of tender years, whose experience is limited and whose beliefs consequently are the function of environment as much as of free and voluntary choice.").

133. Marsh v. Chanbers, 463 U.S. 783, 792 (1983) (upholding state legislative prayer) ("Here, the individual claiming injury by the practice is an adult, presumably not readily susceptible to 'religious indoctrination' . . ...").

134. 482 U.S. 578 (1987); see supra note 131.

135. Aguillard, 482 U.S. at 584 (citations omitted). 
adults as an important factor in Establishment Clause cases. ${ }^{136}$ It helps to explain, for example, why it is not unconstitutional for government to support military or prison chaplains ${ }^{137}$ or to open legislative sessions with a prayer, ${ }^{138}$ and wliy religious colleges may receive tax monies for building grants ${ }^{139}$ while parochial eleinentary schools may not receive public help even for field trips or maps. ${ }^{140}$

Unlike the cases involving adults, the cases involving "religious exercises in the public schools present a unique problein."141 Adults are not as likely to be indoctrinated by the presentation of religious material as are eleinentary schoolchildren, who have not yet formed a strong religious identity. ${ }^{142}$ While adults generally will not misunderstand the governinent's role in a religious activity, ${ }^{143}$ schoolchildren are "very susceptible to the influence of their teachers." 144 Unlike adults wlio may absent themselves if a religious inessage is not to their hiking, ${ }^{145}$ children might not be able to distinguish between a teacher's request for voluntary action and a command that inust be obeyed. ${ }^{146}$ And, of course, children in the public schools have no option to absent theinselves from coinpulsory school attendance.

Thus in any First Amendment inquiry in the elementary school context, the special susceptibility of young children must be taken into account. It is a distinct issue that sharpens any test: ${ }^{147}$ state action that

136. 374 U.S. 203, 252-53 (1963) (Brennan, J., concurring) (distinguishing between college students who attend classes voluntarily and elementary school students whose class attendance is mandatory).

137. Id. at 297-99.

138. Id. at 299-300; cf. Marsh v. Chambers, 463 U.S. 783 (1983) (upholding the Nebraska Legislature's practice of paying a chaplain with tax monies to open sessions with a prayer).

139. See Tilton v. Richardson, 403 U.S. 672, 685-86 (1971) (upholding state grants to religious universities for building construction).

140. Cf. Wolman v. Walter, 433 U.S. 229, 252-55 (1977) (holding state funding of parochial school field trips to be "an impermissible direct aid to sectarian education," relying in part on Meek v. Pittenger, 421 U.S. 349 (1975), which held state funding of maps and charts in parochial schools to be unconstitutional).

141. Schempp, 374 U.S. at 294 (Brennan, J., concurring).

142. See id. at 276 (quoting State ex rel. Finger v. Weedman, 226 N.W. 348, 354 (S.D. 1929), which struck down a policy of expelling Ronian Catholic children front public school for refusal to attend opening exercises where King James version of Bible and Lord's Prayer were read without sectarian coniment, noting that children are "immature, without fixed religious convictions").

143. See Board of Educ. v. Mergens, 496 U.S. 226, 250 (1990).

144. Schempp, 374 U.S. at 262 n.28 (Brennan, J., concurring) (quoting O'Connor v. Hendrick, 96 N.Y.S. 161, 169 (App. Div. 1905), aff'd, 77 N.E. 612 (N.Y. 1906), which held that teachers dressed in Catholic religious garb administering Catholic prayers constituted improper religious training in public school).

145. Id. at 299-300.

146. Id, at $263 \mathrm{n} .28$ (" "[In school] a request and a command have the same meaning. A request from one in authority is understood to be a mere euphemism. It is in fact a command in an inoffensive form." " (quoting State ex rel. Freeman v. Scheve, 93 N.W. 169, 170 (Neb. 1903))).

147. See Edwards v. Aguillard, 482 U.S. 578, 585 (1987) ("[I]n employing the three-pronged Lemon test, we must do so mindful of the particular concerns that arise in the context of public elententary and secondary schools."). 
passes constitutional scrutiny when it affects the general public can constitute impermissible rehgious indoctrimation when it takes place in an elementary school. ${ }^{148}$

\section{B. Testing Christmas Celebrations in the Public Elementary Schools}

\section{The Leinon Test}

In its modern Estabhishment Clause jurisprudence the Supreme Court has generally apphed a test formulated twenty years ago in Lemon v. Kurtzman. ${ }^{149}$ While disagreenent exists over the value of this test ${ }^{150}$ and various members of the Court have at times denied its primacy or attempted to abandon it, ${ }^{151}$ only once since 1971 has the Court decided an Establishment Clause case without referring to Lemon. ${ }^{152}$ Under Lemon v. Kurtzman, government action violates the Establishment Clause if it cannot meet a three-part test: "First, the statute must have a secular legislative purpose; second, its primcipal or primary effect must be one that neither advances nor inhibits religion; finally, the statute must not foster 'an excessive government entanglement with religion." "153 The test is disjunctive: if any branch ${ }^{154}$ is not met, the state program

148. How sharp this inquiry has been is demonstrated by the Court having struck down, with only two exceptions, every public school practice that it has reviewed as possibly officnding the Establishment Clause. See Lee v. Weisman, 112 S. Ct. 2649 (1992) (holding unconstitutional a public middle school's inclusion of clergy offering prayers as part of its official graduation ceremony); Aguillard, 482 U.S. at 583-84 (striking down a statute requiring teaching of "creationscience" if evolution is taught); Wallace v. Jaffree, 472 U.S. 38 (1985) (striking down a statutc that provided a moment of silence for "meditation or voluntary prayer"); Stone v. Graham, 449 U.S. 39 (1980) (per curiam) (striking down a statute requiring posting of the Ten Commandments in classrooins); Epperson v. Arkansas, 393 U.S. 97 (1968) (striking down a statutory ban on the teaching of evolution); School Dist. v. Schempp, 374 U.S. 203 (1963) (striking down teacher-led student recitation of prayers and Bible verses selected by the state); Engel v. Vitale, 370 U.S. 421 (1962) (striking down teacher-led student recitation of state-composed prayer); Illinois ex rel. McCollum v. Board of Educ., 333 U.S. 203 (1948) (striking down a release-tine program involving religious instruction on school grounds). The two exceptions were Board of Education v. Mergens, 496 U.S. 226 (1990) (upholding the practice of permitting extracurricular student religious clubs thc same privileges as nonreligious clubs), and Zorach v. Causon, 343 U.S. 306 (1952) (upholding a release-time program for religious instruction off school grounds).

149. 403 U.S. 602 (1971).

150. Numerous scholars have decried the Lemon test. See, e.g., Jesse H. Choper, The Religion Clauses of the First Amendment: Reconciling the Conflict, 41 U. PITT. L. REv. 673, 681-83 (1980) (criticizing "entanglement" test); Phillip E. Johnson, Concepts and Compromise in First Amendment Religious Doctrine, 72 CAL1F. L. REv. 817, 827-31 (1984) (also criticizing "entanglement" test); John H. Mansfield, The Religion Clauses of the First Amendment and the Philosophy of the Constitution, 72 CAL1F. L. REv. 847, 891-96 (1984) (criticizing "secular purpose" test).

151. See, e.g., County of Allegheny v. ACLU, 492 U.S. 573, 655 (1989) (Kennedy, J., concurring in the judgment in part and dissenting in part); Wallace v. Jaffree, 472 U.S. 38, 68-70 (1985) (O'Connor, J., concurring); id. at 108-13 (1985) (Rehnquist, J., dissenting) (suggesting abandoning the test); Lynch v. Donnelly, 465 U.S. 668, 678-79 (1984).

152. See Marsh v. Chambers, 463 U.S. 783 (1983) (decided primarily on historical grounds, relying on evidence of the framers' original intent with respect to legislative prayer).

153. Lemon, 403 U.S. at 612-13.

154. The branches are "purpose," "effect," and "entanglement." See id. 
fails.

Lemon decided two lower court cases. ${ }^{155}$ Both Rhode Island and Pennsylvania had programs aimed at reducing the financial burden on parochial schools and their einployees by suppleinenting soine teachers' salaries with state funds. Teachers participating in the program were not to spend any time giving rehgious instruction. ${ }^{156}$ In essence, these programs sought to duphcate secular pubhic school instruction in a parochial school setting under the guidance of parochial school administrators. The Court held these programs unconstitutional because they fostered an " 'excessive entanglement' between governinent and rehgion"157 $\mathrm{m}$ violation of the third branch of the Lemon test.

In formulating its test, the Lemon Court looked to past decisions in which tax support of rehgious activity had been upheld. The Court cited Board of Education $v$. Allen ${ }^{158}$ as the source of the first and second parts of the new test, but both branches of this test can be properly, and more clearly, traced to School District $v$. Schempp, decided in 1963:159

The test may be stated as follows: what are the purpose and the primary effect of the enactment? If either is the advancement or inhibition of religion then the enactment exceeds the scope of legislative power as circumscribed by the Constitution. That is to say that to withstand the strictures of the Establishment Clause there must be a secular legislative purpose and a primary effect that neither advances nor inhibits religion. ${ }^{160}$

Neither the first nor second part of the test could resolve the immediate issue in Lemon. The Court was unable to conclude that the legislatures of either Rhode Island or Pennsylvama had intended to advance rehigion with their school-aid programs. ${ }^{161}$ Nor could the Court deter-

155. Id. at 606-07.

156. Id. at 608,610 .

157. Id. at $609,607-11$.

158. 392 U.S. 236 (1968) (lending of textbooks to private school students by public schools did not violate the Establishment Clause).

159. 374 U.S. 203, 222 (1963) (unconstitutional to require the reading of Bible passages and the reciting of the Lord's Prayer in classroom). Schempp cited Everson v. Board of Education, 330 U.S. 1 (1947), and McGowan v. Maryland, 366 U.S. 420 (1960), as sources for the test. Everson upheld a state law reimbursing parents of children in private religious schools for the costs of busing their children to school. 330 U.S. at 16-17. In discussing the impropriety of denying the benefits of "public welfare legislation" to any person on the basis of their faith or lack of faith, the Court cited as an example the public provision of police services to protect parochial school children as well as public school children. Id. at 17. Such services "would serve much the same purpose and accomplish much the same result" as state aid for free transportation of children. Id. McGowan noted that Everson had "found that the purpose and effect of the statute in question was general 'public welfare legislation," "McGowan, 366 U.S. at 443-44 (citation omitted), and applied this reasoning to an analysis of Sunday closing laws. The Court found that these laws emphasized "secular considerations," and therefore did not implicate the Establishment Clause. Id. at 444.

169. Schempp, 374 U.S. at 222 (citations omitted).

161. Lemon, 403 U.S. at 613. 
mine that secular textbooks had in fact been used to teach religion. ${ }^{162}$ Under the Schempp test, the state-aid plans would stand.

The Court's difficulty lay in the fact that it had tried to evaluate establishment of rehigion in the parochial school context under a test developed for the public school context. In the public school, the state is unquestionably the autliority-everything that occurs in the public school is ultimately either at the command of or witl the consent of the state. As the state may not establish any religion, any activity with religious content immediately becomes suspect. Conversely, in the parochial school context religious activity and indoctrination are the norm; ${ }^{163}$ it is state involvement in the religious activity rather than religious activity itself that becomes suspect. The Schempp test, therefore, was inappropriate for the problein im Lemon. ${ }^{164}$

The Court next looked to Walz v. Tax Commission, ${ }^{165}$ a case involving the state's relationship with a rehgious institution. From Walz, which had uplield the exemption of religious organizations from state taxation, the Lemon Court derived the third part of its test prohibiting excessive government entanglement witl religion. ${ }^{166}$ Curiously, the Walz Court had not openly established a new test or even implied that it was consciously modifying the existing Schempp formulation. Rather, recognizing that any government action could occasion some degree of involvement witl rehgion, the Court examined whether an "excessive entanglement" existed so that it could determine the degree to which a state law might permissibly advance or inhibit religion. ${ }^{167}$ The emphasis was on "excessive" rather than "entanglement."168 Indeed, in Walz the Court affirmed ratlier than invalidated the state's grant of tax-exempt status to churches, as it had affirmed the theoretically neutral state-aid

162. Id.

163. See School Dist. v. Ball, 473 U.S. 373, $388-89$ (1985) (striking down a program that provided classes to parochial school students at public expense in classrooms located in and leased from the parochial schools).

164. The Court applied the Schempp test in Board of Education v. Allen, 392 U.S. 236 (1968) (upholding state aid to all students, including parochial school students, in the form of textbook loans), Epperson v. Arkansas, 393 U.S. 97 (1968) (invalidating a state law preventing public school teachers from teaching evolution), and Walz v. Tax Commission, 397 U.S. 664 (1970) (upholding the State's right to exempt religious organizations from general tax laws). Both Allen and Walz applied the Schempp test and found no establishment of religion. In the only public school case, Epperson, establishment of religion was found, however, under the Schempp test. These holdings suggest that the Schempp test would not support a finding of establishment of religion in the private school context and thus that Schempp is the wrong test to use in the private parochial school context.

165. 397 U.S. 664 (1970).

166. Lemon, 403 U.S. at 613 (quoting Walz, 397 U.S. at 674). The Court found "entanglement" in the government's supervision of the parochial schools' ostensibly secular teaching techmiques and educational programs. Id. at 613-14.

167. Id. at 614 ("examin[ing] the form of the relationship for the light that it casts on the substance").

168. Id. 
programs in Everson v. Board of Education ${ }^{169}$ and Board of Education v. Allen. ${ }^{170}$

Since the Lemon decision in 1971, the Supreine Court has heard only two cases in which it was asked to consider the constitutionality of holiday celebrations. ${ }^{171}$ In Lynch $v$. Donnelly, ${ }^{172}$ decided in 1984 , the Court considered the propriety of a city's sponsorship of an annual crèche display as part of a larger commercial Christınas display. ${ }^{173}$ County of Allegheny v. $A C L U,{ }^{174}$ decided in 1989 , likewise concerned a government's public display of a crèche and also required the Court to examme the propriety of a inenoralı displayed side by side with a Christmas tree on the lawn of a public office building. ${ }^{175}$

In Lynch the Court apphied the three branches of the Lemon test, ${ }^{176}$ finding an adequate secular purpose for the crèche display ${ }^{177}$ and no

169. 330 U.S. 1 (1947).

170. 392 U.S. 236 (1968).

171. County of Allegheny v. ACLU, 492 U.S. 573 (1989); Lynch v. Donnelly, 465 U.S. 668 (1984).

Lower courts, however, have addressed the issue on several occasions. For example, in Allen v. Morton, 495 F.2d 65 (D.C. Cir. 1973), the United States Court of Appeals for the District of Columbia Circuit examined the federal government's public display of a crèche. In 1980 the Eighth Circuit decided a question remarkably close to the issue under consideration liere. In Florey v. Sioux Falls School District 49-5, 619 F.2d 1311 (8th Cir.), cert. denied, 449 U.S. 987 (1980), the school district's annual Christmas programs and pageants were challenged but upleld as not overstepping the bounds of propriety under the Establishment Clause. In dissent Judge McMillian recounted the Suprene Court's doctrine favoring the protection of young children from statesupported religious activity. Id. at 1326 (McMillian, J., dissenting). Judge McMillian would have held the school loliday celebrations unconstitutional. Id. For an analysis of the facts and constitutional issues in Florey, see Pevar, supra note 6. Most recently, the Ninth Circuit decided that Hawaii's observance of Good Friday, declaring the day a holiday and allowing many state and local government offices to close, was not an establishment of religion under the Lemon test. See Cammack v. Waihee, 932 F.2d 765 (9th Cir. 1991), cert. denied, 112 S. Ct. 3027 (1992). The case largely follows the spirit that moved the plurality in Allegheny, and therefore does not offer a fresls perspective. See id. at 766-69; infra note 177. The California Suprene Court forbade the City of Los Angeles' annual practice of marking the passage of Easter by illuminating windows in City Hall to form the shape of a cross. Fox v. City of Los Angeles, 587 P.2d 663 (Cal. 1978). The case was decided under the state constitution's religion clause. Because the focus of this Comment is the U.S. Supreme Court's adjudication of the Establishment Clause, these cases are not analyzed further herein.

172. 465 U.S. 668 (1984).

173. A factual description of the pliysical setting of the crèche may be found infra note 188 .

174. 492 U.S. 573 (1989).

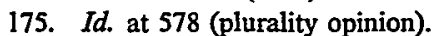

176. Although the Court emphasized that the Lemon test need not be applied at all in Establishment Clause cases, it proceeded nevertlieless to apply the test step by step. See Lynch, 465 U.S. at $678-79$.

177. The city had "principally taken note of a significant listorical religious event long celebrated in the Western World." Id. at 680 . Celebrating the holiday and depicting its origins were held to be legitimate secular purposes. Id. at 681. This step of the analysis in Lynch demonstrates how the Court may allow a religious symbol to escape Establishment Clause prohibition simply by declaring that it is not rehigious but historical. Cf. Stone v. Graham, 449 U.S. 39 (1980) (per curiam) (Court using precisely the same tactic to reach the opposite conclusion with respect to the posting of the Ten Commandments). The Court's willingness to accept such an implausible secular 
excessive entanglement of the government with religion. ${ }^{178}$ The Court's analysis under the effect branch proceeded almost entirely by analogy. ${ }^{179}$ The Court considered the likely effects of the crèche display relative to those of other practices upheld in previous cases: state aid to churchaffiliated schools and universities, ${ }^{180}$ Sunday closing laws, ${ }^{181}$ and legislative prayer. ${ }^{182}$ The Court found that, as in these latter cases, display of the crèche merely happened to coincide with the tenets of some religions ${ }^{183}$ and that any benefit Christianity derived from the coincidence was merely "indirect," "remote," or "incidental"-no more an endorsement of rehgion than a inuseuin exhibit of rehgious paintings. ${ }^{184}$

The underlying rationale in Lynch would lead to clearly objectionable results in the school context. The Court's finding that the Christmas display's purpose was purely historical ${ }^{185}$ would seem to indicate that a crèche display would be appropriate even in the public elementary schools. Indeed, if Christ's birth were considered a purely historical event and Christmas merely the recognition of that event, then the entire Christmas celebration could plausibly be financed by the public school board as a history lesson and provided without discrimination to both public and church schools. ${ }^{186}$ Even those who see no harm in public school Christmas celebrations might find it disturbing to have the gov-

governmental purpose discloses why the purpose test alone might not adequately address the problem raised in this Comment. The Court has, however, demonstrated its unwillingness to accept a government's profession of a secular purpose at face value. See id. at 41; see also Mansfield, supra note 150 , at $891-96$.

The recent Ninth Circuit case, Cammack v. Waihee, 932 F.2d 765 (9th Cir. 1991), cert. denied, 112 S. Ct. 3027 (1992), demonstrated another reason why the purpose test is ineffective against very familiar rehigious observances. In that case, the court concluded that the state chose to observe Good Friday for secular, not rehigious purposes. The legislature ostensibly enacted the holiday to satisfy the need for another holiday during the spring, and to this extent the decision might have been a wholly secular one. Id. at 775-76. Still, the court never analyzed the reasons the legislature came to consider Good Friday as one of the possible alternatives, as opposed to, for example, a randoin Tuesday in April. It is interesting to note that the legislature's alternate choice for a holiday was Lincoh's birthday. Id. at 775. It is inconceivable that the court would have suggested that the choice of Lincoln's birthday would have been arbitrary, having nothing to do with honoring the dead president.

178. Lynch, 465 U.S. at 684 . This conclusion is consistent with the discussion of the Lemon test. See supra text accompanying notes 161-67. One would not expect to find "excessive entanglement" relevant to a religion-m-pubhic scenario because the entanglement test is primarily applicable to the government-in-rehigion problem.

179. Professor Kent Greenawalt proposed such an analogical approach in his article, Religion as a Concept in Constitutional Law, supra note 53, at 762-69, which defined what is religious in a particular case by analogizing to indisputably religious cases.

180. Lynch, 465 U.S. at $681-82$ (citing several cases).

181. Id. at 682 (citing McGowan v. Maryland, 366 U.S. 420 (1961)).

182. Id. (citing Marsh v. Chambers, 463 U.S. 783 (1983)).

183. Id.

184. Id. at 683.

185. See supra note 177.

186. Cf. Wolman v. Walter, 433 U.S. 229 (1977) (upholding public provision of books, standardized testing and scoring, diagnostic hcalth services, and guidance services to parochial 
ernment justify financing religious celebrations ${ }^{187}$ in parochial schools by claiming a historical purpose.

The Court's analysis in Lynch cannot easily be extended to public elementary school holiday observances because of the contextual differences between an open public display and a holiday observance in a classroom. Whatever profane or secular effect the commercial context might have produced in the Lynch crèclie display, ${ }^{188}$ tliat context is not present in the scliool classrooin. On the contrary, the general educational context of seriousness, discipline, and authority suggests that a similar display would be interpreted by children to be part of a larger lesson to be learned. Although school authorities can try to control what they teach to children, the danger of religious indoctrination hes in the fact that teachers cannot control what children will ultimately learn. ${ }^{189}$ And while non-Christian parents can be present to teinper unwanted religious messages their children might get from a public display, they cannot similarly police the classrooin to counter the religious ineaning Christmas holds for Christians. ${ }^{190}$

Following Lynch, the Supreine Court considered the rehigious nature of public Christmas observances again in County of Allegheny v. $A C L U .{ }^{191}$ Allegheny concerned a privately donated crèche displayed on the grand staircase of the Allegheny County courthouse building. ${ }^{192}$ Not far away, on the lawn of the city-county building, the City of Pittsburgh also displayed a forty-five-foot-tall Christmas tree and an eighteen-foottall inenorah along with a sign dedicating the display to liberty. ${ }^{193}$ Ouly

schools); Board of Educ. v. Allen, 392 U.S. 236 (1968) (upholding public provision of secular textbooks to parochial schools).

187. Cf. Allegheny, 492 U.S. at 615 n.62 (plurality opinion) ("If public officials ... participate in the secular celebration of Christmas-by, for example, decorating public places with such secular inages as wreaths, garlands, or Santa Claus figures-they inove closer to the limits of their constitutional power but nevertheless remain within the boundaries set by the Estabhishment Clause." (quotimg Lynch, 465 U.S. at 710-11 (Brennan, J., dissenting))).

188. That display mcluded "a Santa Claus house, reindeer pulling Santa's sleigh, candy-striped poles, a Christmas tree, carolers, cut-out figures representing such characters as a clown, an elephant, and a teddy bear, hundreds of colored lights, a large banner [reading] 'SEASONS GREETINGS,' " as well as the crèche. Lynch, 465 U.S. at 671. The Court has since held that these additional "secular" symbols of Christnas were pivotal in decidimg that the crèche display was constitutional. See Allegheny, 492 U.S. at 598-602.

189. The one lesson children will undoubtedly learn is how to properly observe Christmas, whether or not the observance is openly linked to Christian doctrine. That alone is a lesson nonChristian parents might not want their young children to get in school.

190. Parents must constantly struggle, if only because of a budget constraint, to minimize the impact of commercial messages on their children. Similar vigilance is generally neither required nor practiced with regard to classroom lessons.

191. 492 U.S. 573 (1989).

192. Id. at 579-80 (plurality opinion).

193. Id. at 582, 587. The sign, entitled "Salute to Liberty," bore the mayor's name. Beneath the title it read: "During this holiday season, the City of Pittsburgh salutes hiberty. Let these festive lights remind us that we are the keepers of the flame of liberty and our legacy of freedom." Id. at 582. 
the crèche and the menorah were challenged as offending the First Amendment. ${ }^{194}$

The Court did not consider the purpose and entanglement branches of the Lemon test, as those issues were not presented on appeal. ${ }^{195}$ The Court found that the effect branch of the Lemon test, formulated as "endorsement,"196 demanded an inquiry into the particular context or physical setting of the rehigious presentation. ${ }^{197}$ By comparing the contexts in Lynch and Allegheny, the two cases were distinguished despite the fact that each involved government sponsorship of a crèche. The Court placed particular einphasis on the lack of secularity in the symbols surroundimg the Allegheny crèche-which included floral accents, occasional Christmas choir presentations, and a written banner borne by an angel declaring "Gloria in Excelsis Deol"198 - and on the "unmistakable message" of support and promotion conveyed by placement of the crèche on the grand staircase, ${ }^{199}$ the "main" and "most beautiful" part of the courthouse building. ${ }^{200}$

The Court's rehance on the context in which acknowledged religious symbols are found is confusing and destined to produce unpredictable results. In Lynch, reliance on context suggested that even the most evocative religious symbol can be reduced to constitutional irrelevance when surrounded by a sufficient mass of secular matter. In Allegheny, however, the Court expressly acknowledged that an element of the display that elsewhere would carry no particular religious symbolism-such as the flowers surrounding the crècle-served to heighten rather than detract from the religious significance of the crèche. ${ }^{201}$ Coupled with flowers and the rehigious message "Gloria in Excelsis Deo!" the crèche became an unconstitutional endorsement of religion. ${ }^{202}$ Applied to the

194. Id. at 588 .

195. Id. at 594 n.45.

196. See infra Section III.B.2 (Justice O'Connor's endorsement test).

197. Allegheny, 492 U.S. at 597-601. Blackmun offered this rule both in section III.B of the opimion, in which he was jomed only by Justice Stevens, $i d$. at 597 , and in section IV of the opinion, in which he was joined by a majority, id. at 598.

198. Id. at 580 n.5 (translated as "Glory to God in the Highest").

199. Id. at 600 .

200. Id. at 599 (quoting Brief for Appellants). The Allegheny Court directly rejected the arguments that Christmas is a national holiday and that the city, by merely celebrating the holiday, did not establish religion.

[This argumentl would allow the celebration of the Eucliarist inside a courthouse on Christmas Eve. . . . The government may acknowledge Christmas as a cultural phenomenon, but under the First Amendment it may not observe it as a Christian holy day by suggesting that people praise God for the birth of Jesus.

Id. at 601 .

201. Id. at 599.

202. Id. at 601-02 ("TThe Countyl has chosen to celebrate Christmas in a way that has the effect - of endorsing a patently Christian message: Glory to God for the birth of Jesus Christ. Under Lynch, and the rest of our cases, nothing more is required to demonstrate a violation of the Establishinent Clause."). 
classroom setting, the focus on context could produce bizarre results. For example, it is conceivable that a crèche would be allowed in a public elementary school if it were overshadowed by the clutter of secular school projects and artworks crowding the typical classroom.

Allegheny's rehance on context is disturbing not ouly because it produces inconsistent results but also because the Court did not indicate from whose perspective the context should be viewed. For example, Justice Blackmun, writing only for himself, applied the endorseinent test to the inenorah and Christinas tree, starting from the premise that the Christınas tree alone "is not considered an endorsement of Christian faith." ${ }^{203}$ But he never adequately explained who does not find this to be an endorsement or how he had arrived at that conclusion. ${ }^{204}$ Justice Blackmun recognized that for such a finding, generally one must take into account the views of non-Christians, and he referred to Justice O'Connor's "reasonable observer" standard. ${ }^{205}$ Still, there is nothing in the opinion to suggest that the Justices specifically considered how nonChristians perceive Christmas trees. ${ }^{206}$

Beyond the issue of perspective, Lynch and Allegheny ultimately do not provide a satisfactory answer to the public elementary school holiday question because they did not consider the special circumstances of young children confronted with religious syınbols in a setting established primarily for the purpose of indoctrinating those children. In Allegheny Justice Blackmun explicitly conceded that what might be a constitutional display in front of City Hall might not be so "when located in a public school," 207 but the Court has not yet specifically addressed the issue of public elementary school holiday observances.

It is against this background that I turn now to apply each of the three branches of the Lemon test to public elementary school Christmas holiday observances. Such observances, I will demonstrate, fail all three branches of the Lemon test when considered in the special circumstances

203. Id. at 617.

204. The sources cited for this proposition all suffer from the same narrow perspective. None acknowledge that there might be a large number of non-Christians, concededly the minority in this country, who do not share this secular view of the Christmas tree and other symbols. Indeed, Justice Blackmun and others would have us beheve there are actually two holidays called "Christmas," both falling on the same day: one marks the miraculous virgin birth of the Christian messiah and the other is essentially a national day of good cheer and gift giving, simply part of a "winter-holiday season." Cf. id. at 615-17, nn.62 \& 65.66 (discussing whether the combined display of a Christmas tree, a sign saluting liberty, and a Hannukah menorah endorse religious faith or a secular holiday season).

205. Id. at 620.

206. For example, while Justice O'Connor at one point suggested "the Christmas tree is widely viewed as a secular symbol," id. at 633 (O'Connor, J., concurring in part and in the judginent), she then limited this proposition: "A Christmas tree displayed in front of city hall, in my view, cannot fairly be understood as conveying government endorsement of Christianity." Id.

207. Id. at $620 \mathrm{n} .69$ (plurality opinion) (discussing combined Christmas tree and menorah display). 
of captive public school children and the First Amendment's command that the state not impose religious beliefs upon them.

\section{a. Purpose}

Public school Christmas holiday observances necessarily fail the purpose branch of the Lemon test because Christmas is inescapably a religious looliday, ${ }^{208}$ and therefore it is not possible to imagine any plausible secular reason for the state to be actively involved in this religious activity. No pretense is made that public school children are "studying" Christmas and its attendant practices and rituals-the purpose of school holiday observances is to celebrate Christ's birth with religious hymns and symbolism indistinguisliable from the practices and rituals of Christian families and Christian churches. Sucli celebrations are really just cliurcl services transplanted into the public schools. If the public schools wanted to indoctrinate students in the Christian religion, Christian loliday celebrations would be the way to do so.

Arguinents that these celebrations are secular in nature are unconvincimg. First, they are an insult to Christianity, implying that the Christian faitl has lost all meaning for its adherents and that its message has been trivialized to a secular basis indistinguishable from, say, Motlier's Day. Second, if school authorities really intended to celebrate the secular "winter holiday," they would have programs in the schools focused on, for example, the microeconomics of the season. But children are not engaged in calculating retail profit margins, learning how to staff in anticipation of the holiday shopping bonanza, or plotting merchandizing and sales strategies. The bells are ringing in the scliools, but they are not the bells of cash registers-they are church bells glorifying the birth of Christ.

A government interest $\mathrm{m}$ celebrating the birth of Christ is an impermissible interest. As witl creation science, school prayers, and posting of the Ten Commandments, ${ }^{209}$ the state lias no secular purpose in promoting Christinas loliday celebrations in the schools, and the practice is therefore mvalid under the purpose branch of the Lemon test. What is impermissible to teacli, recite, or post cannot be made permissible if it is sung, acted out in pageants, or presented symbolically. No nonChristian cliild should be forced by the state to sing paeans to the Christ child-anymore than a Christian child should be compelled to keep

208. See supra text accompanying notes 104-17.

209. Each of these public school practices has been held in violation of the Establishment Clause under the purpose branch of the Lemon test. See Edwards v. Aguillard, 482 U.S. 578 (1987) (invalidating a Louisiana statute prohibiting teaching of evolutionary theory unless creation theory was also taught); Wallace v. Jaffree, 472 U.S. 38 (1985) (invalidating a state-mandated classroom minute of silence for meditation or voluntary prayer); Stone v. Graham, 449 U.S. 39 (1980) (per curiam) (invalidating a state law requiring a copy of the Ten Commandments to be posted in each classroom). 
kosher, bow towards Mecca, or cut out lingain and yoni to decorate classroom walls.

\section{b. Effect}

If schoolteachers and administrators beheve they are simply incorporating general American traditions into the classrooin curriculum and not recognizing the religious content of holiday activities and observances, the purpose branch of the Lemon test might be said not to have been violated. Although the true intentions of school officials are a factual matter that cannot be resolved here, I accept that inost school officials probably lack conscious, smister, specific intent to use holiday prograins to indoctrinate children. Nevertheless, the second branch of the Lemon test-tlie effect branch-commands that activities of school officials must have a "principal or primary effect . . . that neither advances nor inhibits rehion." 210 of course, a celebration and glorification of Christ's birth necessarily has the effect of advancing religion, and so it fails to pass constitutional muster under the effect branch of the Lemon test.

The religious trappings of public eleınentary school Christınas celebrations are simply unavoidable-Christmas is inescapably a holiday commemorating and celebrating the birth of Christ, and it cannot be mistaken for a secular occasion. The underlying inessage is a Christian one that will confirm the rehigious beliefs of some children and confuse or offend the religious behiefs of others. ${ }^{211}$ Indeed, if the celebration of Cliristmas lacked a primarily religious effect, Christian churches likely would have abandoned its celebration long ago. The whole point of Cliristmas is inherently religious-it is to send the message to the world that Christ the Savior is born and to promote the adoration of the baby Jesus. The rehigious songs and symbols of Christinas are used by Christians precisely to spread their faith. This message cannot be "balanced" by the inclusion of any amount of secular material-the "secular" loses its meaning in the religious context and serves to proinote rather than neutralize the religious effect. ${ }^{212}$ The rituals and symbols of Cliristınas are designed to liave a religious effect and thus are impermissible in a state-sponsored setting sucli as the public elementary schools.

210. Lemon v. Kurtzman, 403 U.S. 602, 612 (1971).

211. Of course, harm (in the sense of offending non-Christians) is irrelevant in judging the constitutional validity of public elementary school Christmas celebrations-or any state-sponsored religious activity. "First, the Constitution prohibits religious establishments even if everyone wanted them and even if no one was harmed by them. Harm is irrelevant. Second, harm is presumed to exist whenever there is an establishment of religion. Every religious establishment causes harm." Pevar, supra note 6, at $351 \mathrm{n} .111$. The Supreme Court has recognized that "the indirect, coercive pressure upon religious minorities to conform to the prevailing officially approved religion is plain." Engel v. Vitale, 370 U.S. 421, 431 (1962).

212. For an exainple, see supra text accompanying note 201. 
The First Amendment does not permit the state to compel school children to participate in such a sectarian religious exercise.

\section{c. Excessive Entanglement}

Finally under the Lemon test, public elementary school Christmas holiday celebrations fail to pass constitutional scrutiny because they "foster an excessive government entanglement with religion."213 This occurs in two separate ways. First, and most importantly, by celebrating this Christian hohiday the state necessarily aligns itself with a sectarian cause-the celebration and promotion of the Christian religion. The schools side with Christian behevers, throwing their weight on the side of Christian rituals, practices, and symbols. Second, by becoming involved in making a determination of how much religion is permissible in Christmas celebrations and displays, and in decreeing what is religious and what is secular, school officials, state legislatures and the courts have become entangled in sectarian matters. The restriction and surveillance of Christinas celebrations is itself impermissible and can only be avoided by forbidding the state to actively participate in and promote all religious displays, ceremomes, and celebrations. The Court's holiday celebration cases $^{214}$ illustrate this problem-the Justices became excessively entangled in deciding when a crèche is merely historical and when it is an unmistakable message of support and promotion of the Christian faith, and mired in debate concerning the religious and secular status of Christmas trees, menorahs, and other religious symbols. The Court can never be certain that any of these religious symbols has been sufficiently secularized to pass constitutional muster, so it has committed itself to a continual entanglement with rehgion by taking on the task of decreeing what is and is not religious in particular contexts. Such a task of continuous supervision of state-sponsored activity, and the syınbols used therein, entraps both schools and courts in an endless religious controversy that the First Amendment commands be avoided.

\section{Justice O'Connor's Endorsement Test}

In 1984 Justice O'Connor proposed a "clarification" of the purpose and effect branches of the Lemon test in her concurring opinion in Lynch v. Donnelly. ${ }^{215}$ Lynch involved tlie annual Christmas display of a crèche

213. Lemon, 403 U.S. at 613.

214. See supra notes $171-206$ and accompanying text.

215. 465 U.S. 668, 687-88 (1984) (O'Connor, J., concurring); see also Wallace v. Jaffree, 472 U.S. 38, 67-70 (1985) (O'Connor, J., concurring) (laying out the proposed "endorsement test"). Justice O'Connor has promoted her endorsement test in subsequent cases. But cf. School Dist. v. Ball, 473 U.S. 373, 398-400 (1985) (O'Connor, J., concurring) (analyzing the case without reference to the endorsement test).

For commentary supportive of Justice O'Connor's endorsement test, see, e.g., Arnold H. Loewy, Rethinking Government Neutrality Towards Religion Under the Establishment Clause: The 
by the City of Pawtucket, Rhode Island. ${ }^{216}$ Parsing the Lemon test, Justice O'Connor identified two ways in which Establishment Clause violations arise, harking back to the two distinct roots of the test: first, "excessive entangleinent" of government in independent religious institutions is prohibited;" ${ }^{217}$ second, "government endorseinent or disapproval of rehion" is forbidden. ${ }^{218}$

In her concurrence in Wallace $v$. Jaffree, Justice O'Connor offered a further refineinent in her thinking, stating that endorseinent is measured by "whether an objective observer ... would perceive [the activity] as a state endorsement" of rehigion. ${ }^{219}$ The endorseinent test garnered the support of the inajority in County of Allegheny v. $A C L U^{220}$ and is currently an "official" test for Establishment Clause violations.

Before turning to the core concern of Justice O'Connor's endorsement test as it apphies to public eleinentary school Christmas holiday celebrations, it should be noted that such celebrations also violate the excessive entanglement root identified by Justice O'Connor. In Board of Education v. Mergens, ${ }^{221}$ a school district had provided after-school meeting space to various student groups but had tried to deny such accommodation to a Christian club, fearing that to allow the meetings would constitute an estabhishment of rehgion. ${ }^{222}$ A plurality of the Court apphed the Lemon test and found that allowing private rehgious speech, even on school prennises, does not amount to a government endorsement of religion. ${ }^{223}$ Extracurricular, private, after-school clubs are more closely analogous to the private parochial school setting than the public school classrooin because they involve no public school supervision or teaching. For this reason, the excessive entanglement test rather than the effect test was appropriate in Mergens. ${ }^{224}$

Untapped Potential of Justice O'Connor's Insight, 64 N.C. L. REv. 1049 (1986) (explaining the endorsement test and arguing against accepting ingrained, historical practices that violate the Establishment Clause); William P. Marshall, The Concept of Offensiveness in Establishment and Free Exercise Jurisprudence, 66 IND. L.J. 361 (1991) (supporting the endorsement test, but questioning the premise that meinbers of nonendorsed religions should not be inade to feel like outsiders); William P. Marshall, "We Know It When We See It": The Supreme Court and Establishment, $59 \mathrm{~S}$. CAL. L. REV. 495 (1986) (arguing in favor of the endorseinent test because it recognizes the substantial role symbols play in rehigions and the significance of symbolic state action). For a contrary view, see Steven D. Smith, Symbols, Perceptions, and Doctrinal Illusions: Establishment Neutrality and the "No Endorsement" Test, 86 Mich. L. REV. 266 (1987) (arguing that the endorseinent test's focus on symbols inakes it difficult to apply in any principled fashion).

216. For the facts, opinions, and analysis of this case, see supra notes 172-84 and aecompanying text.

217. Lynch, 465 U.S. at 687-88 (O'Connor, J., concurring).

218. Id. at 688 .

219. 472 U.S. 38,76 (1985) (O'Comior, J., concurring).

220. 492 U.S. 573 (1989).

221. 496 U.S. 226 (1990).

222. Id. at 232-33.

223. Id. at $248-53$ (plurality opinion).

224. Id. Once the Court had analyzed the after-school activities as separate froun the school 
Although the facts of Mergens do not suggest the types of endorseinent problems inherent in the celebration and observance of Christian holidays in public schools, much of the Court's analysis focused precisely on an issue that does have important implications for any analysis of public elementary school holiday celebrations. Mergens involved high school students, and Justice O'Connor felt it important to point out just how inuch students at that age resemble university students and how little they resemble elementary scliool students. ${ }^{225}$ "We think that secondary school students are inature enough and are likely to understand that a school does not endorse or support student speech that it merely perinits on a nondiscriminatory basis."226 Because Justice O'Connor's endorsement test focuses on the effect of government speech and actions on the audience, the audience's age and impressionability inust be considered as well as the context in which those actions occur. High school students are expected to understand sophisticated concepts, such as First Amendment rights and the legal and pohtical theories on which such rights are founded. But neither Justice O'Connor nor any other Supreme Court Justice has ever expected elementary-school-age children to possess these same discriminating faculties. "[I]n the eyes of impressionable youngsters," 227 state action such as that approved in Mergens can imply an official endorsement of religion.

A reasonable observer's comparison of the Mergens program and elementary school Christmas activities would note an additional difference beyond the younger age and greater impressionability of the students participating in the latter. The Court in Mergens placed considerable emphasis on the voluntariness of the religious activities and also emphasized that the religious group was only one of inany groups

function-that is, as " noncurriculum related student groups [meeting] on school preinises during noninstructional time," 496 U.S. at 235 (quoting the Equal Access Act, 20 U.S.C. \$ 4071(b) (1988))-the problem became like a release-time ease, such as Zorach v. Clauson, 343 U.S. 306 (1952), which upheld a public school program releasing children for participation in religious classes held off the public school campus and adnimistered and taught by nonpublic school personnel. As in Zorach, Mergens involved no aid to parochial schools and no religious teaching on the part of the public school. Indeed, the Court began its analysis not by referring to any public school case, but rather to School District v. Ball, 473 U.S. 373 (1985), which struck down state payment of salaries for teachers of state-mandated subjects in parochial schools. The proper inquiry in such a case is not whether religion is advanced or endorsed but whether there is excessive governnient entanglentent. The proper focus in Mergens was the school admimistration's lack of involvenient in a way directly affecting the affairs of the Christian club.

225. Mergens, 496 U.S. at 250 (plurality opinion). This was an inportant point strategically because a sinilar policy had already been invalidated for students at a public university in Widmar v. Vincent, 454 U.S. 263 (1981). In that case, Justice O'Connor joined the Court, which noted that "[u]niversity students are, of course, young adults. They are less impressionable than younger students and should be able to appreciate that the University's policy is one of neutrality toward religion." Id. at $274 \mathrm{n} .14$. Drawing a successful parallel with Widmar virtually guaranteed the outcome in Mergens.

226. Mergens, 496 U.S. at 250 (plurality opinion).

227. Id. (quoting School Dist. v. Ball, 473 U.S. 373, 385 (1985)). 
that met after scliool. 228 The religious activity at issue in Christmas celebrations in the public scliools is compulsory, not one of many options from which students may cloose.

It is this setting of impressionable youngsters, compelled to attend school at the command of the state, that is crucial to the application of the endorseinent test to public elementary school Christian lioliday observances. What the endorsement test really asks is whetlier the reasonable observer would conclude that the state intended to advance or inhibit religion-imdicating a violation of the Establishment Clause-or whether the advancement or inhibition was inerely the by-product of general welfare legislation, which would indicate no violation. ${ }^{229}$ If the perspective of the reasonable observer were understood to encompass that of the reasonable non-Christian as well as the Christian observer, and if the special context of elementary-level education were taken into account, public elementary school observance of rehioious holidays would have to be found in violation of the Establishment Clause of the First Amendment.

Taking first the problem of the hidden Christian bias of tlie endorsement test's reasonable observer, I have already argued that this seeningly neutral standard is an illusion and has been applied in a way that reflects a Christian bias. ${ }^{230}$ The perspective of non-Christians is iguored by this observer, who is firmly planted in the Christian faith. It is from witlin this faitl that religious symbols are understood and judged. As a further example of this plienomenon, consider Justice Blackınun's and Justice O'Counor's observations in Allegheny that the menorah is usually taken as a rehigious symbol, ${ }^{231}$ a viewpoint to be expected of most Americans, for whoin the menorah alone miglit represent the Jewisl faitli. But that would liardly be the significance of the inenorah when displayed in Tel Aviv, where most people are Jewisl. Conversely, in countries where most people are not Christian, the Christinas tree and

228. 496 U.S. at 243-47.

229. See Lynch v. Donnelly, 465 U.S. 668, 690 (1984) (O'Connor, J., concurring). Justice O'Connor focused on the individual's "standing in the political community" as the value the Establishment Clause is meant to protect. Id. at 687. "Endorsement sends a message to nonadherents that they are outsiders, not full inembers of the political community, and an accompanying message to adherents that they are insiders, favored members of the political community. Disapproval sends the opposite message." Id. at 688. Linking the First Amendment protection of religious freedom to the unrelated concept of political standing muddies constitutional doctrine. While the Establishment Clause is implicated when schools celebrate religious holidays, Justice O'Connor's focus on standing in the political community is applicable only by analogy to elementary school children. The First Amendment concerns rights of conscience, not just political rights, and protection of First Amendment rights has never depended on whether a person's political standing in the community is affected.

230. See supra notes 203-06.

231. County of Allegheny v. ACLU, 492 U.S. 573, 616 (1989) (plurality opinion); id. at 633 (O'Connor, J., concurring in part and in the judgment). 
associated symbols are seen as symbols of Christianity. ${ }^{232}$

There is an underlying Christian cultural bias within the Court. This bias prevents those who labor under it froin recognizing that for non-Christians the context in which Christmas displays are seen is not the narrow physical context of a flower-bedecked courthouse staircase but is instead the larger social and temporal context in which all such Christmas displays are found. To illustrate: One may ask what it is about a crèche that can make it an unambiguously religious symbol. If presenting the birth of Jesus as a divine event is the indisputably religious eleinent, then presumably a crèche on the courthouse staircase without angels and the words "Glory to God in the Highest!" would pass constitutional muster. ${ }^{233}$ If the rehigious character coines from the depiction of Jesus in any form, then that particular symbol could be reinoved. But would a manger scene on pubhic display at Christmastime without statues of the Biblical characters be any less rehgious? If no distinction results even with the removal of rehigious symbols, then where is the line between the secular and the rehious? Ultimately, it would seem that any display at a city hall between Thanksgiving and New Year's depicting almost any of the eleinents of the story virtually every American will recognize as the miraculous birth of Jesus Christ will have rehgious content and bear a rehgious message. It would hardly be any different if a city simply erected, in twenty-five-foot red and green neon letters, the words "December 25." Even without any apparent religious content or inessage, the effect would be the same: passersby would understand it as the city's commemoration and endorsement of Christinas Day and all that it signifies. In the end, this inquiry should reveal that the teinporal context is at least as important as the physical one in giving Christmas displays their meaning.

But there is a broader context of rehious and cultural experience in which such public displays must be analyzed. ${ }^{234}$ For the inajority of Americans who celebrate Christinas, seeing a Christmas display in public might not suggest the exphicitly religious aspects of the holiday unless recognized rehgious symbols, such as a cross or figures of Jesus, Mary, and the three kings, are included-and even then the message inight be taken as nonrehgious. To non-Christians, who are less familiar with the hohday in their personal experiences, that same Christınas display inıne-

232. Cf. A. Khalique et al., Development of Religious Identity and Ethnocentrism in Indian Children-A Pilot Study, 29 Psychol. Stud. 18, 18-19 (1984) (chart 1) (examining religious identification among Indian students as young as four to five years old by displaying pictures of religious symbols, rites, etc., and using as a symbol of Christians' "important festival" a picture of a Christmas tree).

233. Cf. Lynch v. Donnelly, 465 U.S. 668 (1984) (finding a crèche in a commercial context absent these elements to be constitutional).

234. See Lawrence H. Tribe, american Constitutional Law § 14-15, at 1293 (2d ed. 1988) (endorsement should be evaluated from the perspective of a non-adherent). 
diately carries religious connotations. The non-Christian is not likely to stop to analyze whether particular symbols are present or absent, or even to know what the different symbols represent to Christians. Instead, the display might be seen as a message by and for Christians in their own symbolic language, just as monolingual English speakers might casually disregard the Spanish-language signs in a neigliborhood's shop windows as messages not intended for them while understanding the implicit inessage: "Spanislı spoken here."235

One constitutional scholar recommends that courts should determine whether or not something is religious by judging how closely the subject's characteristics resemble those of the paradigmatically or "imdisputably rehgious."236 But as helpful as sucli an approacl imiglit be, it ultimately relies on an individual judge applying his or her own idea of the indisputably religious, and this idea will vary from judge to judge depending on the judge's rehioious background. It was Justice Blackmun's own religious experience that told him that a Christmas tree does not endorse Christian faith; likewise, his lack of a Jewislı person's experience made it necessary to analytically discuss whether or not a menorah symbolizes Jewish faitl. ${ }^{237}$ The Court's claim that tlie "reasonable observer" would find no religious symbolism or message in a forty-fivefoot-tall higlted Christmas tree in front of city hall on December 25tl suggests that there is no room in Establishınent Clause jurisprudence for the opmions of the reasonable Jew, Muslim, Hindu, or atheist-tlie "reasonable observer" is in reality a "reasonable Cliristian."

When this biased "reasonable observer" is asked to make judgments in the special context of elementary-level education, the result is that Christian rituals, practices, and symbols fail to be recoginzed for what they really are: an estabhisliment of religion-state-sponsored religious indoctrination of those persons in society, young children, who are least able to recognize proselytism and resist it. Christmas celebrations in the public elementary schools are not merely the by-product of general welfare legislation; they plainly are a message that the Christian religion is favored or preferred, and thus fail to pass constitutional muster when examined by a genuinely impartial, reasonable observer heeding Justice O'Connor's endorsement test.

235. Cf. Anya P. Royce, Ethnic Identity: Strategies of Diversity 149 (1982) (contrasting the symbol set used by the ethnic group to identify its members with that reduced set used by outsiders to recognize the group).

236. Greenawalt, supra note 53 , at 767 .

237. Compare County of Allegheny v. ACLU, 492 U.S. 573, 613 (1989) (plurality opinion) ("The menorah, one must recognize, is a religious symbol . . . ") with id. at 616 ("The Christmas tree, unlike the menorah, is not itself a religious symbol."). 


\section{Justice Kennedy's Coercion Test}

This is not yet really a test but rather an indication of the direction in which the Court's growing conservative faction might be heading. ${ }^{238}$ In his opinion in County of Allegheny v. ACLU Justice Kennedy rejected Justice O'Connor's endorseinent test as "a recent, and in iny view inost unwelcoine, addition to our tangled Establishment Clause jurisprudence"239 that was insensitive to "our lieritage" and bordered on "latent hostility toward religion." ${ }^{40}$ Believing that religion inust be recognized and accommodated by the state, Justice Kennedy located the "great object" of Establishment Clause jurisprudence in Marsh v. Chambers, ${ }^{241}$ which had upheld the practice of legislative prayer based on its long history and which he believed "stands for the proposition, not that specific practices common in 1791 are an exception to the otherwise broad sweep of the Establishment Clause, but rather that the ineaning of the Clause is to be determined by reference to historical practices and understandings." 242 The two limiting principles in the Court's cases at "the border between accommodation and establishment" were, he believed, that government may not coerce anyone to support or participate in any religion or its exercise; and it may not, in the guise of avoiding hostility or callous indifference, give direct benefits to religion in such a degree that it in fact "establishes a [state] religion or religious faith, or tends to do so."243

Thus, "coercion is the sole touchstone of an Establishment Clause violation." 244 As possible indicators of coercion, Justice Kennedy suggested being "compelled to observe or participate in any religious ceremony or activity," contribution by a city or county of "significant amounts of tax money," and the absence of freedom "to ignore" the state's messages and symbols of religious holidays. ${ }^{245}$

Without going into the nuances of Justice Kennedy's viewpoint, the persuasiveness of his doctrinal analysis, or the many surprising and unwelcome results his formulation might portend in other contexts, one can see that public elementary school Christmas celebrations fail to pass constitutional muster when subjected to his coercion test. First, as the Court itself emphasized in upholding the legislature's practice in

238. A number of commentators have proposed tests based on whether state action is "coercive." See, e.g., Michael W. McConnell, Coercion: The Lost Element of Establishment, 27 WM. \& MARY L. REV. 933 (1986).

239. 492 U.S. 573, 668 (1989) (Kennedy, J., concurring in the judgment in part and dissenting in part).

240. Id. at 657.

241. 463 U.S. 783 (1983).

242. Allegheny, 492 U.S. at 670 (Kennedy, J., concurring in the judgment in part and dissenting in part).

243. Id. at 659 (quoting Lynch v. Donnelly, 465 U.S. 668, 678 (1984)).

244. Id. at 660 .

245. Id. at 664 . 
Marsh, ${ }^{246}$ the audience of that prayer was an adult one, "not readily susceptible to 'religious indoctrination." "247 Second, public elementary school Christmas celebrations "place the government's weight behind an obvious effort to proselytize on behalf of a particular religion."248 Indeed, no non-Christian rehigious hohidays are generally recognized by public schools. The long Christmas holday, and the Christian ritual, practice, and symbolism inherent in its celebration in the schools, fulfill each and every one of Justice Kennedy's indicators of coercion: elementary sclioolchildren are compelled to observe and participate in Christian religious ceremony and activity; the public schools are supported by significant amounts of tax money and in Christmas celebrations this tax money "serve[s] tlie cause of one religious faith"; ${ }^{249}$ and schoolchildren, compelled by compulsory attendance laws proinulgated by the state, are not free to ignore these celebrations nor to "turn their backs."250 These public school Christmas celebrations do not present a risk of "tlie first step down the road to an establishment of religion"251 - they are an establishinent of religion.

The listorical argument proves too inucl, as to both ancient and American history. Whether the birth of Clirist as depicted and celebrated at Cliristmas is properly understood as history or inythology is one of the prime questions defiming the religious differences among us. ${ }^{252}$ As American history and tradition, celebration of Christmas, at least in the public schools, is no more legitimate than would be celebration of slavery, the exclusive male franchise, or any other practices that do not comport with the commands of the Constitution as we understand them today. Religion simply does not liave to be accommodated in this wayeven were the government to cease all its support of Christian ritual in the public elementary scliools, Christmas would continue to be celebrated by Christians unimpeded in their hoines and churches, and the public celebration of the secular, mercantile lioliday that is an American tradition would not be harmed in any way. Cliristmas and Cliristianity do not depend on state indoctrination of schoolchildren. As this coer-

246. 463 U.S. 783 (1983).

247. Id. at 792 (quoting Tilton v. Richardson, 403 U.S. 672,686 (1971)).

248. Allegheny, 492 U.S. at 661 (Kennedy, J., concurring in the judgment in part and dissenting in part).

249. Id. at 664.

250. Id.

251. Id.

252. See, e.g., Lynch v. Donnelly, 465 U.S. 668,708 \& n.14 (Brennan, J., dissenting) (the distinction "constitute[s] the ultimate division between Judaism and Christianity" (quoting M. BUber, ISRAel aNd THE WORLD (1948), reprinted in Disputation and Dialogue: Readings IN THE JEWISH-CHRISTIAN ENCOUNTER 281-82 (F. Talmage ed., 1975))). Even were the historical accuracy of Jesus not in dispute, the history is of interest to many precisely because of its religious significance, not simply because of its antiquíity. 
cion is both unnecessary and unconstitutional, there is no reason-least of all one based on tradition or nostalgia - to continue it.

Whatever the ultimate fate of Justice Kennedy's coercion test, the Supreme Court did not attempt to apply it in a formalistic way when deciding the most recent Establishment Clause cliallenge to a public scliool practice. In Lee v. Weisman, ${ }^{253}$ the Court forbade the inclusion of clergy whio offer prayers as part of an official public school graduation ceremony. Justice Kennedy, writing for the Court, noted that the controlling precedents as they relate to prayer and religious exercise demand "heightened concerns with protecting freedom of conscience from subtle coercive pressure im the elementary and secondary public schools"254 because in "the classroom setting ... the risk of compulsion is especially lighl"255_" "the student [is] left witl no alternative but to submit."256 This context requires that public scliool cases be distinguished from Marsh v. Chambers. ${ }^{257}$ Indeed, im any context, "a literal application of the coercion test would render the Establishment Clause a virtual nullity ...."258 Thus, the coercion test, regardless of any validity in otler contexts, is not strictly, and certainly not woodenly, applicable in the public school context. And as I have already argued, even if it were, it would result im public scliool Cliristian lioliday observances being found unconstitutional.

\section{IV \\ CONCLUSION}

The difference in the way Christmas is experienced by the Cliristian and by the non-Christian cliild leads to the failure of public elementary school observances of Christmas to pass muster under any constitutional test. Scliool observances of Cliristmas endorse, and thus advance, the Christian rehigion by reinforcing the lome experience and private religious training and identification of Christians. Simultaneously, school observances of Christmas disapprove of otlier religions by inliibiting the religious identification of non-Christians with their own families' religious traditions. The most vulnerable and innocent members of society are thus given the message that their religion is either approved of or disapproved of by their teaclier, their scliool, and their government.

Religious minorities are made to feel uncomfortable-even bitter-

253. 112 S. Ct. 2649 (1992) (affirming application of three-part Establishment Clause test set forth in Lemon v. Kurtzman, 403 U.S. 602 (1971), by district court and court of appeals).

254. Id. at 2658.

255. Id. at 2660 .

256. Id.

257. Id. at 2660-61. "[T]his is not a case like Marsh v. Chambers, in which government officials invoke spiritual inspiration entirely for their own benefit without directing any religious message at the citizens they lead." Id. at 2678 n.8 (Souter, J., concurring) (citation omitted).

258. Id. at 2673. 
when the state insists on celebrating the Christian religion in the public scinools. ${ }^{259}$ And such celebrations are of no coinfort to Christians, whose religion is debased and secularized when what they regard as a sacred occasion is celebrated in a less than sacred inanner. The evil here is that the sacred is inade profane when the state incorporates a religious activity into the stream of secular life. The interest of both minorities and the majority is that the state keep out of religious life. Nothing is gained by state celebrations of Christmas in the public elementary schools-but, ultimately, everything of true religious value miglit be lost. Rehigion is inherently a matter of private conscience, not a matter that should be handed over to the care of the state. The only way that the state can recognize and accommodate religion is to stay out of it entirely.

The Court has found official endorsement and disapproval of religion to be prohibited by the First Amendment. As Justice Douglas observed in School District v. Schempp, "[t]he vice of all . . . arrangements [of administering religious practices in schools] is that the state is lending its assistance to a cliurch's efforts to gam and keep adherents."260 Education of young children-even in secular matters-is in its essence indoctrination. ${ }^{261}$ When Christmas rituals becoine an integral part of the educational process, they have the primary effect of inducting very young children into the traditions and practices of the Christian religion.

I have not taken issue with all use of religious texts, music, and history in the public schools. As the Court itself observed in its Schempp decision, presentation of the Bible is appropriate in the classroom when it is part of a real educational lesson. ${ }^{262}$ Public schools may teach about religion as long as they do not observe retigious rituals or teach children what to believe. ${ }^{263}$ Especially for high-school-age children, whom the Court has found to be less susceptible to iniproper religious influences, reading and analyzing selected passages from the Bible, learining to understand and appreciate the context, history, and teciniques of religious art, and learning to perform music or sing songs originally composed in praise of a Christian God, all can be legitimate educational enterprises.

259. See The Supreme Court, 1983 Term, 98 HARv. L. REV. 1, 182-83 (1984) ("The entire period of the Christmas hohday season, characterized by learning Christmas carols in public schools and seeing Christmas displays in stores, vividly reminds religious minorities of their differences with and alienation from the dominant Christian culture.").

260. 374 U.S. 203, 228 (1963) (Douglas, J., concurring) (school prayer and Bible-reading prohibited).

261. See Board of Educ. v. Pico, 457 U.S. 853, 876 (1982) (Blackmun, J., concurring in part and in the judgment) (entirely appropriate for public schools to "inculcat[e] fundamental values"); id. at 879 ("IS]chool is designed to, and inevitably will, inculcate ways of thought and outlooks ...."); $c f$. Roe, supra note 87 , passim (work of schools should not be to inculcate values but rather to develop students' capacities to think for themselves).

262. Schempp, 374 U.S. at 225.

263. Id. at 224-25. 
But under the same standard, government cannot justify having public elementary school children read Christmas stories, create Christmas art and decorations, sing Christmas carols, or decorate the classroom and exchange gifts at Christmastime. Even if an art, music, or reading lesson focuses on a Christinas theme occasionally throughout a grade-school career, the repetition of such activities year after year in the same seasonal context can leave no doubt that such holiday observances stand apart from other coursework. Simply put, studying religion is constitutionally permissible; practicing it is not.

Finally, I have not taken issue with the Court's present method of analyzing religious establishment cases. Rather, I have proposed a careful application of the various constitutional tests that encoinpasses, first, a proper understanding of the special protection needed for elementary school students and, second, a fair recognition of the views of nonCliristians. When the Court faces a challenge to Christmas holiday observances in the public elementary schools it must take into account the reasonable non-Christian members of American society if it is to faithfully uphold the Establishment Clause of the First Amendment. 